fisicas e que sejam domiciliadas no mesmo Estado contratante. Em contrapartida, não há mais possibilidade de reserva.

10 Schröder, loc. cit., supra note 17, p. 534

11 P. 159.

12 Nesse sentido, Fragistas, p. 238

13 O C.P.C. de Zurique, art. II permite, ao contrário, uma cláusula desse gênero (citada supra I, 1)

14 O ante-projeto da Convenção paralela propõe uma fórmula um pouco mais restrita inspirada no art. 9 da Convençāo da Naçōes Unidas sobre os contratos de venda internacional de mercadoril de 1980 (Convenção de Viena).

15 Citado supra, nota 1 . Ele dá conta, sobretudo, da gênese da cláusula e da jurisprudència relativa. Ver igualmente a critica da cláusulas não exclusivas em
H.U. Walder-Bohner, p. 681 .

16 Affaire 22/85, Clunet 1987 p

105, $22 / 85$, Clune 1987 p. 474, IPRax 1987,

105 , Recuel

17 P. 345 e nota 32

18 Bulletin officiel de l'Assemblée fédèrale, mars 1985 . p. 129.

19 Bulletin officiel, septembre 1986, p. 1302.

20 Bulletin officiel, février 1987, p. 976 .

21 EuGVÜ, Nos 68-72, ad art. 17, p. 190

22 No mesmo sentido, o relatório Schlosser, relativo ao texto de 1978, J. O. des Commaunautés européennes. C 59, 5 de março de 1979, no 178; Cf. J. Kropholler, nota 142, p. 191; ver a nota de M.A. Huet relativa à decisáo da Corte de Apelação de Paris de 27 de março de 1987, Journal du Droit International (Clunet), p. 141, 1988

23 Cour de Cassation, $1^{\circ}$ de abril de 1985 , Rivista di Diritto internazionale privato e processuale 1986 , p. 863, e Oberlandesgericht München, 13 de fevereiro de 1985, ibid., p. 931; ver igualmente 0 artigo de S. Mariatti, ibid., p. 819

24 Bulletin officiel, mars 1985, p. 129.

25 Bulletin officiel, septembre 1986, p. 1302.

27 Segundo C.H. Fischer, p. 143
28 Por razōes históricas, os tribunais suiços faziam esse duplo controle no quadro da Convenção FrancoSuica, ab-rogada com efeito $\mathrm{em}^{1}$ de janeiro de 1992; ver C. E. Dubler, La reconnaissance et execution des decisions etrangeres en Suisse. Relatórios suiços apresentados no XII Congresso Internacional de Direito Comparado, Publications de l'Institut suisse de droit comparé, $n^{\circ} 7$, Zurich 1987 , p. 29 , spéc. p. 49.

29 Nesse sentido. C. E. Dubler, op. cit., supra nota 28. Convenção Suiça-Tchecoslováquia, art. 1., Cap. 1.; Convenção Suiça-RFA, art. 1. in fine: Convenção Suiça-ltallia, art. 2., alinea 2 ; Convençăo Suiça-Austria, art. 1., capitulo 1.: Convenção Suiça-Liechtens-
tein, art. $1 .$, in fine.

31 Tribunal de la Seine, 10 janeiro 1962, Revue crittque de droit international prive 1963, p. 607 , note Foyer $G$ de Geouffe de la Pradelle, $n^{2} 966$, 440 Battifol. dacarde II no 718 , note 6 , no mesmo sentido.

32 Ver D. Martiny, Handbuch des internationalen $\mathrm{Zi}$ vilverfahrensrechts, Band III/1, Tübingen 1984, $\mathrm{n}^{\circ}$ 652 e nota 1932, p. 300; ver também Keller/Siehr. p. 580. A opiniáo majoritáia nos foi confirmada pelo professor K. Siehr. No mesmo sentido, 0 art. 32 , alinea 2, du Civil Jurisdiction and Judgments Act, 1982, do Reino Unido.

33 Isto, ao menos, se nos admitirmos, o que parece ser a opiniāo dominante, que os Estados do Mercado Comum tèm a obrigaçao de náo reconhecer a decisáo de um Estado terceiro que viole as regras de foro absolutas do art. 16 da Convenção de Bruxelas, mesmo se este foro for situado em um outro Estado da Comunidade (ver sobre este ponto, Jayme, p. 107 e p. 118, nota 61). Seria diferente se 0 locatário tivesse tido seu domicilio na Alemanha, porque o tratado germano-suiço, de 2 de novembro de 1929 , nào obriga a respeitar a competència exclusiva de um outro Estado e a obrigaçáo de recogacão que ente do art 16, cap primeiro da Convenção de Bruxelas. (Nesse sentido, Kropholler. EuGVŪ, $\mathrm{n}^{0} 20$, ad. art. 25, p. 241).

\title{
Imprensa. Captação Audiovisual. Informática e os Direitos da Personalidade*
}

ANTÔNIO CHAVES

Professor das Faculdades Metropolitanas Unidas de São Paulo

SUMÁRIO

PARTE I - 1. Imprensa: Jornais, Periódicos; 2. Desgarra-se o Conceito Tradicional de "Imprensa" para o de Informação; 3. Mas Não Apenas a Lei, Como o Próprio Jornalismo Precisa Ser Renovado; 4. Dynabook, o Livro do Futuro; 5. Uma Nova Forma de Editar: CD-ROMs; 6. Fotografias Publicadas pela Imprensa; PARTE II: 7. O Que E Que Se Entende por Captação Audiovisual?; 8. Definição de Obra "Multimidia" ou Eletrônica; 9. O Audiovisua Como Sistema; 10. O Video on Demand (VoD); 11. Internet; 12. A Orientaçãa do Governo; 13. Como Caracterizar uma "Criação" Eletrônica?; PARTE III - 14. A Importância da Programação Cibernética; 15. Uso do Banco de Dados; 16. Imprensa e Informática; 17. Direitos da Personalidade; 18. O Embate Entre a Liberdade de Informação e os Direitos da Personalidade; 19. Limites do Direito de Informação; 20. Divulgaçãa de Fatos Relativos a Persona22. Na Indenização dos Danos Morais Não Mais Prevalece a Tarifa dos arts. 51 e 52 da Lei 5.250/67; Bibliografia.

PARTE I

\section{Imprensa: Jornais, Periódicos}

Não nos permite a amplitude dos assuntos aprofundar o estudo do tema imprensa.

Limitemo-nos a referir que Darcy Arruda Miranda, Comentários à Lei de Imprensa, S. Paulo, Ed. Rev. dos Tribunais, 3.ed., 1995, localiza a madrugada da imprensa nada menos que nos simbolos ou sinais em que, desde a idade da pedra (paleolitica e neolitica) os homens transmitiam os seus pensamentos por meio de incisões e pinturas rupestres.

Já no ano de 1750 a.C., sob o reinado de Thoutmés III, existia um jornal oficial, e ao tempo do Farao Amarsis, jornais satíricos lhe alfinetava a administração. Com Jaques Bourquin, La Liberté de la Presse, 1950, p. 35 registra que na China existiu em Pequim, para mais de 1.300 anos, um jornal: King-Pao.

Os romanos tinham jornais ou atas diurnas que circulavam de maneira regular e, por meio do serviço postal, levavam aos extremos da República ou do Império as novidades de Roma.
No século $\mathrm{XV}$, Veneza enviava aos seus embaixadores e agentes, espalhados pelo mundo, as "fogli d'avizzi", com notícias escritas a mão, dai surgindo a primeira "Gazzetta".

Acompanha a evolução da imprensa no País desde as suas primeiras manifestaçōes, bem como a evolução das leis, até o advento da de n 5.250, de 09-2-1967.

Podemos definir imprensa, no sentido que aqui interessa, como jornal, periódico ou folha noticiosa, e, por extensão, os meios de comunicação em massa escrita ou falada que transmitem noticias e informações.

Garante a Constituição a toda a pessoa, em seu art. $5^{\circ}$, inc. IV: "a livre manifestação do pensamento, sendo vedado o anonimato" e, no inciso $\mathrm{V}$, assegura o direito de resposta "além da indenização por dano material, moral ou à imagem".

0 principio é reiterado, com mais ênfase, no art. 220 , não admitindo $0 \S 1^{\circ}$ que qualquer lei contenha dispositivo que possa constituir embaraço à plena liberdade de informação jornalistica em qualquer veículo de comunicação so- 
cial, observados os incisos que enumera 0 art. $5^{\circ}$.

É da tradição do nosso direito, pois já constava da Constituição do Império, art. $179 \S 4^{0} \mathrm{e}$ da de 1967 , art. $150, \S 8^{\circ}$, reiterado na Lei $n^{0}$ 5.250, de 09-2-1967, em seu art. $1^{\circ}$ :

"É livre a manifestação do pensamento e a procura, o recebimento e a difusão de informações ou idéias, por qualquer meio, e sem dependência de censura, respondendo, cada um, nos termos da lei, pelos abusos que coum, nos

\section{Desgarra-se o Conceito Tradicional de "Imprensa" para o de Informação}

A amplitude do conceito de jornalista, exorbitando do conceito popular de que seria quem escreve para jornais e revistas, já podia ser depreendido do art. $2^{\circ}$ da Lei 4.529 , de 13 de janeiro de 1959, considerando jornalista profissional aquele cuja função, remunerada e habitual, compreendida a busca ou documentação de informaçōes, inclusive fotograficamente, a redação de matéria a ser publicada, contivesse ou não comentários, a revisão de matéria composta tipograficamente, a ilustração por desenho ou outro meio do que for publicado, a recepção radiotelegráfica e telefônica de noticiário nas redaçōes de empresas jornalisticas, a organização, orientação e direção de todos esses trabalhos e serviços.

Sofreu revisão no Dec.-Lei $n^{0}$ 972, de 17-101969 , que dispõe sobre o exercício da profissão de jornalista que recebeu nova regulamentação pelo Dec. 83.284, de 13-3-1969, em decorrência das alterações introduzidas pela Lei $n^{0} 6.612$, de 07-12-1978.

Enumera o Dec. 83.284 no art. $2^{\circ}$ as atividades que o exercicio habitual e remunerado da profissão de jornalista compreende, privativamente:

"I - redação, condensação, titulação, interpretação, correção ou coordenação de matéria a ser divulgada, contenha ou não comentário;

II - comentário ou crônica, por meio de quaisquer veiculos de comunicação;

III - entrevista, inquérito ou reportagem, escrita ou falada;
IV - planejamento, organização e direção e eventual execução de serviços técnicos de Jornalismo, como os de arquivo, ilustração ou distribuição gráfica de matéria a ser divulgada;

$\mathrm{V}$ - planejamento, organização e administração técnica dos serviços de que trata 0 item I;

VI - ensino de técnicas de Jornalismo; VI - coleta de noticias ou informações e seu preparo para divulgação;

VIII - revisão de originais de matéria jornalistica, com vistas à correção redacional e à adequaçắo da linguagem;

IX - organização e conservação de arquivo jornalistico e pesquisa dos respectivos dados para elaboração de notícias;

$\mathrm{X}$ - execução da distribuição gráfica de texto, fotografia ou ilustração de caráter jornalístico para fins de divulgação:

$\mathrm{XI}$ - execução de desenhos artísticos ou técnicos de caráter jornalístico, para fins de divulgação."

$O$ artigo 11 classifica as funções desempenhadas pelos Jornalistas, como empregados, dando-lhes as definiçōes correspondentes: redator, noticiarista, repórter, repórter de setor, radiorreporter, arquivista-pesquisador, revisor, llustrador, repórter fotográfico, repórter cinematográfico, diagramador.

Vale assinalar, no entanto, ter ac. un. da $4^{\mathrm{a}}$ Turma do TRT, $I^{a} \mathrm{R}$. de 18-7-1984, RO 9.493, rel. Juiz Oldenir de Almeida, ADV 180825, num caso de redatora de noticiário considerado irrelevante para o Direito do trabalho o titulo que a empregadora tenha dado ao cargo exercido pelo empregado. $\mathrm{O}$ que importa é o contrato realidade, isto é, as funções realmente exercidas. Se exerce funçōes de relatora, é jornalista a teor do $\S 1^{\circ}$ do art. 302 da CLT - Recurso impróvido.

A profissão é hoje regulamentada pela Lei $n^{\circ}$ 6.612 de 07-12-1978.

Os dispositivos da CLT e da CLPS atinentes à matéria foram revogados pelo novo regulamento, Dec. 83.284, de 13-3-1979.

Detectava, já lá vão mais de 20 anos, Teófilo Cavalcanti Filho, aos 20-7-1964, não se confundir o jornal moderno, em sua imensa complexidade, com a simplicidade de material técnico e humano que caracterizava o jornal antigo. Neste, 0 elemento intelectual era tudo nele,
0 aspecto predominante era a redação, era 0 comentário, era a crítica, em suas várias manifestações.

No jornal moderno, o elemento que predominava antes cedeu lugar ao objetivo informativo. que hoje constitui a sua principal caracteristica.

Tão relevante é esse aspecto, que mais de uma legislação substitui a denominação de imprensa pela de informação, sendo ainda exato que há mesmo as que preferem organizar códigos leis de informação, ao invés da tradicional lei de imprensa.

Mesmo entre nós, não foram poucos que sugeriram iniciativas dessa natureza, que romperia, se concretizada, com uma tradição secular, que vem desde os primórdios da nacionalidade

Não obstante o peso da tradição, forçoso é convir que de certo modo a sugestão atende à exigências técnicas que regem e cercam a informação em nossos dias. Partindo desse elemento, que fundamental, o conceito de jornalist necessariamente teria que passar, como de fato passou, por alterações substanciais.

É que, para propiciar a informação, tanto desempenha um papel relevante $o$ cronista que tece finas consideraçōes a respeito de um acontecimento como o técnico em radiotelegrafia, que recebe e transmite a noticia, ou o ilustrador que elabora uma charge a respeito dela.

Todos eles cada um no seu setor, cada um a seu modo, colaboram no trabalho de divulgação e informação, de modo a permitir que 0 acontecimento seja percebido e analisado pelo grand público.

Passa a demonstrar como os nossos Tribunais já se aperceberam dessa evolução, proclamando, com ênfase, que 0 conceito de jornalist se alargou.

Assim, ac. da $4^{\mathrm{a}}$ Câmara do TASP esclarece que, "para os efeitos da lei, o conceito jornalis deve ser entendido em sentido lato, compreendendo todos aqueles que trabalham em qualquer dos setores da atividade jornalistica

Observa que a citada lei 3.529 nada mais fez do que dar guarida a uma inclinação geral, estimulada pelas considerações a que alude, e que já se revelara mesmo no sistema da Consolidação das Leis do Trabalho (art. 302, parágrafo $\left.1^{\circ}\right)$ e do decreto-lei $n^{0} 7.037$, de 10 de novembro de 1944, artigo $3^{\circ}$. Já trabalhando sobre esses dispositivos, a jurisprudência alargara o conceito, para nele incluir certas categorias que, rigorosamente, nele não se achavam incluidas como se pode depreender do acórdão inserto na Revista dos Tribunais, vol. 286/661 e 301/534.

Foi graças ao mesmo espírito que sempre se entendeu que o revisor sempre integrou a classe dos jornalistas, consoante se vê dos acórdãos publicados na Revista de Direito Administrativo, vols. 38/181; 49/101; 52/100; 56/142.

Não se pense, aliás que - conclui - que as coisas ficarão por aí. Se há um setor, em que a técnica opera prodigios, é o da informação. Novas mudanças que ocorram terão, também, conseqüencias no mundo juridico. $\mathrm{E}$ näo é improvavel que novas categorias venham a compor a categoria dos jornalistas.

Encontra-se na Câmara dos Deputados, desde 1992, Projeto de nova Lei, destinado a substituir a que vigora desde a época da ditadura militar, elaborado por comissão composta pelos juristas Evandro Lins e Silva, René Ariel Dotti, João Luiz Faria Neto, Leônidas Rangel Xausa, Luis Francisco de Carvalho Filho e Manoel Alceu Ferreira.

Assegura o direito de resposta proporcional ao agrafo: I - na mesma página do jornal ou periódico, com destaque, dimensões e caracteres tipográficos, no título e no texto, idênticos ao escrito ofensivo e em edição com tiragem normal; II - na transmissão, na mesma dimensão ou duração, pela agência noticiosa, por todos os meios de informação e divulgação através dos quais foi transmitida a noticia ofensiva; III na transmissão com a mesma duração, no mesmo horário e no mesmo programa da emissora que divulgou a transmissão que lhe deu causa, garantido o minimo de um minuto. 0 texto também prevê que a publicação ou transmissão da resposta será nula se, pelo acréscimo de comentários assumir o caráter de réplica ou se não atender os requisitos estabelecidos na lei (Jornal do Conselho Federal da OAB, nº 42/1995, p. 16).

\section{Mas Não Apenas a Lei, Como o Próprio}

\section{Jornalismo Precisa Ser Renovado}

É o que apregoa Henry A. Grunwald, ex-redator chefe da revista Time e ex-embaixador dos EUA na Áustria, em Diálogo, Rio de Janeiro, no 
3, vol. 27, 1994, pp. 62-64, apontando nada menos de seis novos fatores com que se depara a imprensa: história, geografia, visão global agenda jornalistica, sensibilidade e audiência.

Faz ver que as forças da informação estão implodindo através dos limites convencionais além do controle dos meios de comunicação de massa regulares. $O$ candidato independente Ross Perot é, em certo sentido, um guerrilheiro computadorizado. Na campanha eleitoral de 1992 ele utilizou a última palavra em computador telefone e tecnologia para reunir uma enorme organização em tempo incrivelmente curto.

Ele transmitiu sua mensagem em entrevistas ao vivo no rádio e na televisão, que constituem os principais novos catalisadores de público irado e favorável. Se o "comício urbano eletrôni$\mathrm{co}^{\prime}$ ainda não existe, è certamente exeqüivel evocando a altamente turbulenta visão do referendum instantâneo sobre todos os assuntos concebiveis.

Os americanos muito em breve teriam, como já temos também, sistemas de televisão a cabo com centenas de canais, famintos de alimentação programática. Existirão muitos serviços nos levando constantemente para perto das acoes, levando constantemente para pe inclusive açöes politicas em todos os niveis. As companhias telefônicas poderão entrar no negócio da informação. Os meios de comunicação de massa tradicionais reduzirão ainda mais seu papel de mediadores entre os acontecimen tos e o público. Em resumo, a força que era instrumental em derrubar o Muro de Berlim poderá derrubar muitos muros na sociedade americana.

Entre este desconcertante tumulto de comunicação, quem prestará atenção ao que e ao quão cuidadosamente? Separar a verdade da falsida de, o fato da propaganda, o sentimentalismo do argumento será mais dificil do que antes. Isto não será, certamente, o fim do jornalismo, mas não será, certamente, o fim do jornalismo, mas
de muitas maneiras o principio de um novo jornalismo.

\section{Dynabook, o Livro do Futuro}

Mas também os bibliotecários terão que se haver, em breve com outros instrumentos de trabalho.
Há vinte anos Allan Kay, um cientista norte americano da Xerox Corporation previu o aparecimento, por volta de 1990, do "livro dinâmico": um computador portátil, de baixo consumo de energia, com o tamanho e aspecto de um livro. Ao ser aberto, mostraria duas telas em forma de páginas, onde apareceriam textos e ilustrações, em cores, e com legibilidade perfeita, igual à de um livro impresso. Só que este livro dinâmico seria, na realidade, milhares ou milhōes de livros em um só. Pressionando uma tecla ou encostando o dedo nas páginas, o leitor provocaria "um virar de páginas" eletrônico, permitindo avançar e recuar no texto. Uma gigantesca capacidade interna da memória e pequenos cartuchos removiveis de memória garantiriam uma biblioteca eletronica inesgotavel à disposiça do feliz possuidor de tal maraviha.

E o que informa Renato Sabatini, Professor da Universidade Estadual de Campinas (UNICAMP), onde dirige o Núcleo de Informática $\mathrm{Bi}$ omédica, com o "Dinabook", milhares de livros num só, "O Estado de São Paulo", Caderno de Empresas, 07-06-1988, p. 3, acrescentando dattarem apenas 20 a $30 \%$ da tecnologia necessária para a construção de um livro desses.

Já dispomos, com efeito, dos "paper-white video monitors", com resolução gráfica altissima: telas que mimetizam as páginas de um livro, mas não portáteis. Além disso, hoje, já possivel comprimir-se 200 milhões de caracteres em um cartão de plástico metalizado, do tamanho de um cartão de credito Isto darla para armazenar 500 livros de 200 páginas cada um! Estes cartōes, que utilizam a mesma tecnologia laser dos discos compactos (CD), devem evoluir para um bilhão de caracteres de capacidade, de modo a permitir ainda armazenar confortavelmente 200 livros, ou tambem livros, ou também sons em estéreo.

Ressalta a importância da matéria com 0 exemplo do problema do armazenamento e re cuperação de informações na área médica.

Já naquela ocasião eram adicionadas ao conhecimento mundial cerca de um milhão de palavras por hora, publicadas em mais de seis mil livros novos por mês, e mais de 25 mil revistas e outros tipos de periódicos. A maior biblioteca médica do mundo (a National Library of
Medicine, situada em Washington, nos EUA) tem em seu acervo mais de 600 mil livros médicos, e cerca de 12 milhões de artigos impressos, Para armazenar apenas os títulos e nomes de autores destas obras è necessário um gigantesco ar senal de computadores, os maiores que são fabricados atualmente. E o pior è que, segundo própria NLM admite, ela não chega a cobrir $50 \%$ de tudo que é publicado em Medicina, em níve mundial.

Torna-se cada vez mais impossivel localizarse o conhecimento desejado e manter-se em dia com a evolução do conhecimento mesmo em áreas extremamente especializadas. Só na informática médica, por exemplo existem mais de 700 livros publicados, além de 60 e tantas revistas em todo o mundo.

O Dynabook, não só seria um livro eletrônico, mas também um livro inteligente. Com um pouco mais de tecnologia, ele poderá até "conversar", "raciocinar" e "argumentar" com o seu leitor, tornando a aquisição do conhecimento uma coisa dinâmica e divertida. Aliás, este era 0 intuito original de Kay, ao propor o Dynabook a revoluçáo na sala de aula.

Em matéria de editoração eletrônica informa Rodolfo Lucena, enviado especial a Montain View, EUA, na Folha de S. Paulo de 02.08.1995 p. 6-3, que a nova versão "Pagemaker" usado para produzir por computador desde documentos e folhetos até páginas de jornal, funcionando com Macintosh, da Apple, apresenta 50 novos recursos em relação à versão anterior, incluindo mais cores, facilidades para tratamento de imagens e ferramentas para edição de texto e figuras.

Foram ampliadas também as possibilidades de criação de páginas básicas ("master pages") "São páginas que vêm sempre com algumas ca racteristicas iguais - um desenho no lado esracteristicas iguais - um desenh
querdo superior, por exemplo.

$\mathrm{Na}$ versão anterior, era possivel ter duas pàginas básicas; agora, dá para trabalhar com até 256.

Por exemplo, é possivel incluir comentários sobre design de uma página ou sobre um texto e marcar esses comentários para que não apareçam na hora da impressão do documento. Isso pode evitar erros ou situaçōes embaraçosas, como a de observaçōes vistas por olhos indesejados."

\section{Uma Nova Forma de Editar: CD-ROMs}

Unindo divulgação gráfica à multimidia, descobrindo o mercado editorial de CD-ROMs cinco das maiores editoras, Nova Fronteira, Ática, Globo, Record e Companhia das Letras - informa Daniel Piza em Folha de S. Paulo de 30 de junho de 1995 , p. 5-3 - se preparam para aferir o potencial dessa nova forma de consumo cultural.

A empreitada exige mudanças estruturais nas editoras. A Ática e a Globo já criaram divisões para cuidar do setor: a Ática Multimidia e a Globo Multimidia.

A Record fez parceria com a empresa Montreal Tecnologia, que acaba de lançar o CD-ROM "Jorge Amado - Vida e Obra: e prepara para breve "Tabuleiro de Damas", de Fernando Sabino.

A Nova Fronteira, pioneira no lançamento do CD-ROM do Dicionário Aurélio, que desde fevereiro vendeu 6.000 cópias, tem projetos em andamento como um dicionário inglês-português.

A Companhia das Letras ainda não têm divisão especial. Mas já se acerta com produtoras multimidia para testar o mercado.

Começa pela Companhia das Letrinhas, que anca em outubro um CD-ROM, produzido pela Acme Design, reunindo três de seus livros infantis (leia mais abaixo)

A Companhia das Letras já escolheu seu título de estréia: Guia dos Curiosos", de Marcelo Duarte sem data definida, mas para este ano, Outro projeto em curso é "Chico Buarque Letra e Versos" com as canções do compositor.

Na mesma página complementa a reportagem local que a Ática quer repetir nos CD-ROMs sua liderança no setor de livros didáticos. Nada menos que 15 títulos estão em preparação pela Ática Multimidia.

Livros de inglês e história, por exemplo, ganham versão em CD-ROM.

Mas segundo o diretor da divisão de multimídia, Gilberto Mariot, "em geral não é boa idéia pegar o que foi concebido impresso e fazer uma versão eletrônica". 
Mariot acha que o CD-ROM obtém melhor resultado quando concebido diretamente para
o meio. Isso significa que, como o consumidor é criança, historinhas e clima de "game" (jogo) são recursos imprescindiveis.

É o que a Ática está fazendo com "A História usuário dispõe de uma "máquina do tempo" viaja por paises e épocas. "É perfeito para o meio eletrônico", diz Mariot, "porque é quase um eletrônico", diz Mariot, "porque e quase
"game" e sai da fórmula "Era uma vez..."."

Outro projeto em andamento é um CD-ROM de literatura brasileira, com texto de Marisa Lajolo, que lança mão do humor. O usuário se credencia na Academia Brasileira de Letras e, à medida que acerta os exercícios, atinge diferentes "niveis de imortalidade".

Mariot conta que o percurso completo da produção - direitos autorais, video, áudio, design arte final, tiragem e distribuição (de 3.000 cóp as) - è caro: custa entre US\$150 mil US\$250 mil.

Mas Mariot acha que o público potencial do mercado vai compensar o custo dos CD-ROM (que tem o preço médio de $\mathrm{R} \$ 40$ atualmente) "Calculo que em São Paulo deva haver uns 40 mil usuários de multimidia; no Brasil, uns 200 mil", diz, baseando-se em vendas de alguma revistas no formato de CD-ROM no pais.

Maria Gama, finalmente informa a respeito do CD-ROM dedicado ao cineasta Frederico Fe llini (1920-1993) é um livro eletrônico: não tem as pirotecnias habituais dos titulos em multimidia e é feito para ser consultado.

Mas, apesar do formato simples e da abundância de textos, não serve só para cinéfilos. Os trechos de filmes e trilhas sonoras - de 30 segundos cada - são os atrativos para o público não especializado.

"Fellini on CD-ROM" é o primeiro dos CDROMs "de conteúdo" que a empresa MSD, especializada em games, importa para o Brasil. Fo produzido pela Editel (filiada à IBM) e pela Rizzoli, uma das maiores editoras italianas. É um dos títulos do consớrcio internacional Emme que congrega estúdios e editoras da Europa e EUA. A importadora deve trazer um CD-ROM sobre Michelangelo e outro sobre Van Gogh.

\section{Fotografias Publicadas Pela Imprensa}

Amiúdam-se os casos de pedidos de indenização relativos as fotografias, o que não é de se estranhar: à medida que se multiplica o uso de um produto, dá margem a cruzamento de interesses e inevitáveis conflitos.

Numa hipótese dessa natureza, ac. un. da $1^{\mathbf{a}}$ Câm. Civ. do TJPR, de 15-3-1994, na Ap. 26.512, Rel. Des. Tadeu Costa, Adv. 67.617 reconheceu que embora o delito de difamação, praticado pela imprensa falada ou escrita, só se puna a titulo de dolo, em sede de responsabilidade civil a culpa strictu sensu é o bastante para justificar a indenização.

$A D V$, sob o $n^{0} 36070$, divulgou inédito acórdão da $6^{\mathrm{a}}$ Câm. Civ. TJ-RJ, reg/ em 08-8-87, Ap. 5.220, Rel. Des. Basileu Ribeiro admitindo ação de indenização por extravio de filme entregue para revelação, mandando fixar indenização pelo dano moral ocorrido, independentemente da reparação do dano material.

E logo em seguida, $\mathrm{n}^{0} 36069$, aresto unânime da $2^{a}$ Câm. Civ. TJ-RS de 19-9-87, Rel. Mário Lopes, estabelecendo distinção entre a imagem como atributo da personalidade e o direito do autor da fotografia, aquele pertence ao retratado, este ao fotógrafo. Assim, ainda que se pudesse admitir que 0 autor da obra fotográfica tivesse efetivamente transacionado com a demandada, alienando a esta a obra fotografica, a difusão da imagem só poderia ser feita evidentemente se e com autorização do demandante. Como a demandada não exibiu esta autorização e tal autorização não pode ser vista no recibo passado pela demandante e 0 autor da fotografia, obviamente estava a demandada legitimada para funcionar no pólo passivo. Por zões, é de se dar provimento ao apelo, determinado seja enfrentando o mérito da demanda depois de regularmente instruida a causa.

Trata-se de uma distinção de alta relevância, por estabelecer discriminação entre duas "provincias" do direito cujas lindes ainda não estão perfeitamente assentadas: a dos direitos da personalidade e a dos direitos de autor.

Esta, na verdade, cometeu verdadeira invasão em detrimento daquela, situação que aca- bou por se consolidar pela complacência de tão grande número de manifestaçōes jurisprudenciais, que não resta outra solução se não conformarmo-nos com o fato consumado.

Perfeita compreensão da matéria revela acór dão unânime de 01-10-87 da Quinta Câmara Civil do TJ-SP, nos autos de Ap. Civ. 89.799-1, SP, registrado no Livro 2031, fls. 32-35: ação ordinária movida pela modelo fotográfico Elizabeth Thais Pucci, reclamando indenização pelos danos, inclusive lucros cessantes, que sofreu em virtude da utilização de sua imagem em veiculos de propaganda da empresa Yakult $S / A$ Indústria e Comércio para os quais não dera autorização.

Interposto apelo da decisão que julgou procedente a demanda, com a condenação da ré ao pagamento da indenização a ser fixada por ar bitramento, com os adminiculos legais, considerou o Relator, Des. Ralpho Waldo, ter o M. Juiz de Direito decidido bem todas as questōes que foram submetidas a seu julgamento.

Reconhece que a cliente-usuária dos serviços de publicidade não manteve contato direto com a modelo fotográfico que acabou por participar da propaganda de seu produto, uma ve que o contrato feito com a moça a ligou à empresa que se encarregou da prestação dos serviços de publicidade propriamente ditos (criação e planejamento da publicidade e arregimentação dos profissionais, inclusive através de agências especializadas, como as de modelos)

A agência de modelos não apresentou a autora nem contratou em seu nome, mas apenas apresentou como candidata ao serviço de publicidade.

Por outro lado, a cliente-usuária realiza com a empresa de publicidade, a Junco, no caso, um contrato que mais se aproxima da locação de serviços, em que a nota predominante é a subordinação desta àquela, no que tange ao plan da campanha e à sua execução, dependentes que sảo da aprovação e autorização da primeira.

A empresa de publicidade não só contrata a modelo que foi aprovada e escolhida pela cliente-usuária, como também a contrata para determinado plano ou campanha de publicidade de acordo com a autorização da cliente-usuá ria, e, pois, por conta e risco desta.
Por aí jả se vê que a ampliação da campanha publicitária, quer dizer, a utilização da imagem da autora em meios de propaganda por ela não autorizados, só pode ser imputada à apelante, a única empresa, portanto que podia ocupar o pólo passivo da relação jurídica processual; e que ela nenhum direito de regresso poderia ter contra a Junco, empresa de publicidade que, como se disse, apenas planejou e executou a campanha publicitária autorizada e ordenada pela Yakult.

Não se cuidava no caso de responsabilidade contratual, mas de culpa aquiliana, porque a ampliação do uso da imagem da autora ocorreu fora dos termos do contrato, resultado da violação de um dever fundado num principio geral de direito.

Quanto ao mérito, era mesmo de rigor o decreto de procedência da ação, uma vez que a ora apelante, ao autorizar a utilização da imagem da autora em meios de propaganda por ela não autorizados, violou seu direito, como protegido pela lei, à preservação da própria imagem e à impossibilidade juridica de reprodução sem sua expressa autorização, que assegura em última análise, o direito à própria personalidade.

De acordo com a Doutrina e Jurisprudência pátrias, "a imagem é emanação da própria pessoa e, pois, de elementos visiveis que integram a personalidade humana, de caracteres físicos que individualizam a pessoa", de modo que sua reprodução somente pode ser autorizada pela pessoa a quem pertence (RJ-TJ, vol, 95/74).

Destarte, basta o fato da publicação não autorizada para ensejar a indenização, não cabendo sequer indagar, a rigor, se houve dano efetivo, material ou moral, ou se a publicidade foi causa de enriquecimento ilicito.

$\mathrm{Na}$ espécie, esclareceram as provas que a modelo autorizara, realmente, tão-só a publicação de sua foto num número da revista "Playboy", não a sua utilização em outros meios de propagandas, em campanha publicitária que restou alargada por iniciativa da apelante.

Como se não bastasse o pormenor de que a Yakult nenhuma prova forneceu de que estava autorizada a publicar a foto da autora em cartazetes, "posters" e luminárias, que foram expostos em farmácias e aeroportos, está nos autos a fatura apresentada pela própria contes- 
tante, a qual dá conta de que o agenciamento da modelo fez-se só para veicular anúncio em revistas masculinas.

Como bem demonstrou o Magistrado em sua sentença, toda a importância paga à modelo $\mathrm{CCr}$ $53.330,00$ ), incluidos os descontos relativos ao Imposto de Renda e ISS), referia-se àquele anúncio, dai a inferência de que sua autorização realmente se dera em termos limitados.

O próprio valor do pagamento feito, relativamente baixo, tanto que pouco superior a dois salários-mínimos então vigentes, confirma a conclusão.

Induvidoso, por outro lado, que a divulgação ampla da foto da modelo, do que deu noticia segura a prova dos autos, inclusive a testemunhal, trouxe-lhe prejuizo efetivo: primeiro, é inegável que a popularização da imagem de uma modelo fotográfico pode ser negativa sob diver sos aspectos, mesmo porque é compreensivel que certas campanhas publicitárias exijam rostos pouco conhecidos desvinculados de outros produtos; em segundo, porque é evidente que, estando em curso uma campanha publicitária, em que atue certa modelo, nem sempre haverá interesse de outra empresa na utilização concomitante da mesma imagem.

Confira-se, a propósito, a noticia de que Thais Pucci teria ficado conhecida como a "moça da Yakult".

Como se vê, existe certeza quanto à ocorrência de prejuizos, a qual não fica elidida pela relatividade daqueles conceitos, dai resultante a obrigatoriedade da indenização a que foi condenada a ré.

Por último, a nota de que toda a questão do valor da indenização (do "quantum debeatur") ficou relegada para a execução da sentença, no que andou bem o magistrado da Primeira Instância, porque a prova dos autos, mormente pericial, realizada apenas sob o aspecto contábil, não se orientou no sentido de fixá-lo.

Nessa fase processual, portanto, será apurado o "quantum debeatur", decidindo o Juiz então sobre as verbas que correspondem ao rea prejuizo da autora.

O julgamento teve a participação dos Desembargadores Marco César e Märcio Bonilha, com votos vencedores.
0 remédio parcial, por insatisfatório que seja será procurar confinar o direito à imagem da pessoa retratada, nos casos comuns, entre os direitos da personalidade, e colocar, no direito de autor, na condição de "conexo", o direito à imagem de artistas, atletas, autores célebres, modelos profissionais ou pessoas notórias.

No TJSP, a 4ª̂mara, na AC 111.127, Rel. Des. Ney Almada, Rev. Juridica 174/147, n 5.569 não admitiu a existência de responsabilidade civil por dano moral em virtude de publicação de fotografia em revista sem permissão. Tratava-se de matéria de cunho informativo, que não visa injuriar direito algum, sendo a pretensão, além do mais, incompativel com a referente do direito à imagem.

\section{PARTE II}

\section{O Que É Que Se Entende Por Captação} Audiovisual?

Captar é o ato de pegar, apanhar, segurar, prender.

Refere-se pois, a tudo quanto a mente humana alcança através dos dois sentidos da audição e da vista. Os que deles são providos gozam com as maravilhas que a cada instante proporcionam à nossa sensibilidade: a natureza, com suas formas e cores infinitas, as construcoes e maquinismos que o homem edifo prop que 0 homem edifica incessantemente, a própria movimentação dos seres em sua constante alacridade, as harmonias, e, principalmente, sua fixação para que, como por milagre, ressuscitar a cada momento.

Ou, como sempre, melhor dito por Milton Fernandes: "os meios de captação audiovisual coletam e propagam, através da percepção sensorial acústica e óptica, dados imagens e informaçōes.

Não há como abordar o tema sem evocar a lição desse Mestre ao advertir que os meios de captação audiovisual coletam e propagam, através da percepcão sensorial acustica e optica, vés da percepcáo sensorial acust dados, imagens e informaçôes, apontando os erdadeiros milagres que a eletrônica vem obtendo nos dois campos: as paredes têm olhos $\mathrm{e}$ ouvidos eletrônicos.
Com G. Moffa, conselheiro da Corte de Apelação de Roma, mostra que, em uma sociedade dominada por um desenvolvimento prodigioso da técnica, é necessário o reforço das norma que garantem os direitos fundamentais da dignidade da pessoa.

Realça a dificuldade da preservaçāo da intimidade diante dos prodígios da ciência, esbarrando em fatos de complicada catalogação e seleciona, dos mandamentos apontados por Pierre Juvigny, durante o II Colóquio Internaciona sobre a Convenção européia dos Direitos do Homem:

- interdição ou disciplina da industrialização do comércio interno e externo de certos objetos;

- enumeração legal das autoridades e pessoas que podem utilizá-los;

- adaptação ou reforço dos poderes de Cortes e Tribunais, com a possibilidade de ordenarem a apreensão do objeto, a desnutrição dos registros;

- afirmação peremptória do direito à repa-

ração do dano causado às vítimas;

- endurecimento das leis penais em matéria de difamação;

- extensão ao rádio e à TV do direito de re tificação.

Duas noticias publicadas na Folha de S. Pau lo dão idéia da dimensão que atinge hoje a captação audiovisual.

De Nova York informa Daniela Falcão ter Walt Disney Company anunciado no dia 31 de julho de 1995 a compra da Capital Cities Incorporation, proprietária da rede de televisão $\mathrm{ABC}$ por US\$ 19 bilhōes, na maior fusão de empresas de comunicação nos EUA.

A Capital Cities tem dez estaçōes de TV $A B C$ é a maior) que detém $25 \%$ do mercado norte-americano, além de 225 afiliadas em todos os EUA.

Também é proprietária de 21 estações de rádio, vários jornais de circulação estadual guias de compras. Tem participaçoes em quatro canais nos EUA (ESPN, ESPN 2, A\&E TV e Life time TV) e outros no Japão, Alemanha, França, Inglaterra e Escandinávia.

E a Reportagem local dá conta, na edição de 01-8-1995, Especial, p. 3, existirem no Bras cerca de 32 milhões de aparelhos de TV (um para cada cinco habitante), mas só 600 mil residências, em todo o país, têm acesso à programacoes exclusivas das TVs por assinatura.

É um dos maiores mercado a serem explorados em todo o mundo. Sozinho, equivale à metade do da América Latina.

O número de assinantes cresce $10 \%$ ao mês e segundo os empresários, 0 mercado tem potencial para 6 milhões de usuários. Prevê-se um faturamento de US\$2,9 bilhões por ano só em pagamento de mensalidade, sem contar receita publicitária e de outros serviços.

A TV por assinatura, com exceção das transmissões diretas por satélites, depende de concessão do governo, que até agora só deu 101 permissões para Tvs a cabo e 12 para transmis-
são por microondas, também chamado MMDS. Só existem concessōes para TV a cabo em dez Estados, enquanto as de MMDS estão restritas a nove capitais. Cidades grandes como Salvador e Vitória ainda não dispõem de nenhum tipo de TV paga.

\section{Definição de Obra "Multimídia" ou}

\section{Eletrônica}

Eis ai uma operação estimulante, mas delicada, envolvendo freqüentemente não apenas 0 direito à imagem, como também problemas relativos ao direito intelectual.

É, para Pierre-Yves Gautier, Professor da Universidade de Caen Baixa-Normandia, "a criação complexa que reúne, depois de colocada em forma informática, um conjunto de textos, de imagens fixas e/ou animadas ou de música, acessivel em um "disco compacto" (CD-ROM para simples leitura, CDI para o diálogo), que necessita a utilização de um aparelho (leitor separado ou inserido num computador, uma televisão, etc.) para que os usuários possam dela tomar conhecimento."

$\mathrm{Na}$ análise a que procede dos direitos implícitos na realização, distingue os principais dos derivados.

"O processo utilizado para a realização, a duplicação e a comunicação da obra "multimidia" consiste indubitavelmente numa reprodução no sentido do art. 122-3 (da lei francesa): "fixação material da obra mediante qualquer procedimento que permita comu- 
nicá-la ao público de um modo indireto... ou magnético (isto é impressão em suporte visual ou sonoro)."

Está em jogo, pois, acrescenta em nota, triplamente, o direito de reprodução: em primeiro lugar, a fixação da obra "multimédia" em um suporte eletrônico, em seguida, duplicação mediante tiragem, para os exemplares postos em comércio e finalmente comunicação ao público mediante o recurso de um aparelho.

\section{O Audiovisual Como Sistema}

Sob esse titulo comenta e compendia a Prof Paula Monteiro, livre-docente do Departamento de Antropologia da USP, no Jornal de Resenhas da Folha de S. Paulo, 07-8-1995, Especial-8, livro Televisão, Publicidade e Cultura de Massas de José Mário Ortiz Ramos, Vozes, 293p.

Começa evocando aquilo que Guy Debord denominou de "sociedade do espetáculo": emerge quando a produção da cultura se faz em escala industrial, visando a um mercado de massa. "O espetáculo não pode ser visto apenas como o excesso de um mundo da visão, o simples produto de técnicas de difusão de imagens em massa. Para Debord, a sociedade do espetáculo uma maneira de ver o mundo que se materializa. Este talvez seja o pano de fundo, o não dito que dá a verdadeira força da argumentação que José Mário Ortiz Ramos desenvolve em seu livro sobre o sistema audiovisual no Brasil. Ao colocar a produção da imagem no centro de sua reflexão, o autor desloca inteiramente a linha de argumentação - centrada nos intelectuais e n cultura erudita - que até muito recentemente alimentou o debate em torno da cultura brasileira, e enfrenta o desafio de demonstrar como por que essa 'parte maldita' da produção cultural que é a cultura de massa se torna progressivamente um dos setores mais importantes $n$ produção de nosso imaginário.

Em primeiro lugar põe em evidência o fato de que o campo de produção de imagens opera como um sistema no qual cinema, televisão publicidade mantêm entre si um movimento continuo de competição e associação. Em segundo lugar, porque ela torna evidente que nessa rela ção o setor mais forte, e aquele que se tornara referência para o campo, será o setor que mais rapidamente for capaz de definir um padrão eficiente de produção audiovisual.

\section{O Vídeo on Demand (VoD)}

Nesse desenvolvimento da Cabo TV temos a possibilidade dos usuarios de TV ligarem, mediante pagamento, seus televisores por cabo telefônico a um banco de dados a cujo acervo acedem escolhendo filmes, videos, programas, etc., com a ulterior vantagem de controlarem o desempenho mediante pausas, retornos e desenvolvimento mais ou menos veloz das cenas.

$\dot{E}$, pois, como define Alfonso Contaldo, Video on Demand: Problematiche giuridiche della TV Interativa, "II Diritto di Autore, Janeiro-Março 1995, pp. 105-127, "um novo e articulado medium, porquanto representa a primeira tentativa de convergência entre a tecnologia própria das telecomunicações e $\mathrm{a}$ da televisão.

Tornará a veiculação desses serviços, que podem ser assimilados de algum modo aos da TV, o VoD um sistema de TV ou se desvincula da tecnologia de transmissão a sua natureza de serviço telemático?

Realça a enorme importância da resposta à pergunta, pois, no primeiro caso encontrariam aplicação analógica as regras previstas para a TV Cabo, compativeis também com as para a TV por meio de ponte-rádio, não passando então o VoD de uma forma par ransmissão de dados cujo terminal e constituido por um aparelho de televisão, - ao passo que no segundo caso só poderiam ser serviços de televisão, com exceção das televendas, cujo programa seria visto em horários e dias diferentes por um público diversificado, parecem aproximarse mais às vendas telematicas, embora enriquecidas por um video animado, no conceito de Cardarelli, Zeno-Zencovich, Profili Giuridici della televisione via cavo interattivo (video-on-demand) in Dir. Inform., 1994, 709.

A se levarem em conta, finalmente, as modalidades de fruição dos servicos, estes não poderiam ser, a rigor, considerados de TV, tendo em vista o fato que esta seria exclusiva e não diferenciada pelo uso coligado, pois os serviços VoD são comunicados a cada um dos usuários, depois de obtido acesso a uma especial data-base, individualmente, nunca de modo massificado.
Por entre uma série de considerações relativas à legislação italiana apresenta dois problemas: o da possibilidade de se distribuirem de um lado filmes que não tenham sido autorizados a serem apresentados ao público ou mesmo proibidos, e, de outro lado, quanto tempo deva decorrer desde o momento da distribuição no salōes do cinema a o por meio do VoD.

Existe ainda o problema da censura, que embora abolida em nosso pais, é exercida por via da pressão de pessoas e entidades mais conservadoras.

Valem também para 0 nosso pais as incertezas postas em realce por Alfonso Contaldo, a espera de uma oportuna regulamentação legislativa, conjuntamente com a da TV Cabo.

Enquanto que na Itália pode ser invocado, por analogia, o Código Postal, objeto do Decreto Legislativo $\mathrm{n}^{\circ} 73$, de 1991 , exigindo a distribuição dos programas de cabo-TV mediante autorização do Ministério dos Correios, nem pensar. pelo obsoletismo, de recorrer à nossa Lei $n^{0}$ 6.538, de 22-6-1978, que Dispóe sobre os Serviços Postais.

A Constituição Federal de 05-10-1988 atribui competência à União, art. $21, \mathrm{n}^{\circ} \mathrm{XI}$, explorar, diretamente ou mediante concessão a empresas sob controle acionário estatal, os serviços telefônicos, telegráficos, de transmissão de dados e demais serviços públicos de telecomunicações, assegurada a prestação de informaçoes por entidades de direito privado através da rede pública de telecomunicações explorada pela União e $\mathrm{n}^{0}$ XII, explorar, diretamente ou mediante autorização, concessão ou permissão: a) os serviços de radiodifusão sonora, de sons e imagens e demais serviços de telecomunicações.

Compete-lhe ainda, privativamente art. 22

IV, legislar sobre águas, energia, informática, telecomunicações e radiodifusão.

Reserva ao Congresso Nacional, art. 48, com a sanção do Presidente da República, dispor sobre todas as matérias de competência da União, especialmente sobre, entre - 14, XII telecomunicações e radiodifusão.

Arcaica também a legislação sobre telecomunicaçōes: Código Brasileiro, Lei 4.117, de 27-8 1962 e Regulamento Geral aprovado para sua execução, Dec. no 52.026, de 20-5-1963.

O Decreto $n^{0}$ 52.795, de 31-10-1963, que fusão cuida, no Capitulo V, das retransmissões, no VI, das estacōes retransmissoras e no Titulo IX das redes de radiodifusão.

\section{Internet}

Maria Ercilia ocupa uma página inteira, a de no 7 , do Caderno Especial da Folha de S. Paulo de 01-8-1995 a essa rede mundial de comunicacão por computador, com presença em $47 \mathrm{mil}$ redes, em 159 paises e número de usuários estimado em 40 milhōes. Permite o uso de correio eletrônico e transferências de programas e arquivos de som, imagem e texto digitalizado.

Surgiu como um rede subsidiada de educação e pesquisas nos EUA.

No Brasil é administrada pela Rede Nacional de Pesquisas, que se prepara para fornecer acesso comercial a empresas a partir desse mês de julho, embora seu acesso comercial já existisse nos EUA há seis anos.

Estrearam então, via Embratel que fornece acesso a algumas empresas e usuários, em caráter de projeto piloto, os primeiros provedores de acesso para o cidadão comum. Até então, 0 acesso era limitado ao meio acadêmico e funcionários públicos.

0 provedor de acesso permite a usuários conectarem-se à rede. A conexão do usuário ao provedor é feita por linha telefônica.

A Internet tem um número de usuários calculado hoje em 40 milhões, a estimativa é que chegue a 100 milhões em 96.

O preço da assinatura do BR Home Shopping é de $R \$ 40$ por mês, que dão direito a 20 horas de uso. A hora adicional custa $\mathrm{R} \$ 4$. 0 Rural fornece conexões especiais para empresas, com maior capacidade, a preços que variam entre $R \$ 800$ e $R \$ 1.500$ ao mês.

A IBM se prepara para começar a fornecer acesso à Internet a partir do final deste mês, através de sua rede internacional, a GSI. A empresa está fazendo testes finais de seu software de acesso e serviço de suporte ao cliente.

0 gerente de desenvolvimento de novos negócios da empresa, Raimundo Martins, afirma que num primeiro momento haverá pontos de conexão no Rio de Janeiro e em São Paulo.

A IBM ainda não tem previsão do custo da assinatura. 
A Microsoft Network, será uma rede fechada num primeiro momento, e passa a dar acesso Internet no ano que vem. No Brasil, deve estrear em Janeiro.

A Abril lança em outubro o serviço de acesso Abril Online. A empresa fez um pré-cadastramento durante a Fenasoft, no qual 3 mil pessoas de inscreveram. Segundo Antônio Machado. diretor-superintendente do Projeto Online do Grupo Abril, a empresa pretende ter um serviço provedor de acesso à Internet, em que o consumidor poderá encontrar produtos da Abril, como versões eletrônicas de revistas. Machado afirma que o investimento na instalação do serviço fo de US\$ 1 milhão.

No Brasil, o número de usuário da rede acadêmica da Internet é hoje de 45 mil. 0 número de microcomputadores pessoais no pais é de 1.7 milhões, e o número de linhas telefônicas é de 13 milhões.

O Banco Rural, de Belo Horizonte, estreou seu serviço de acesso à rede, o BR Home Shop ping, no dia 13 de julho. Segundo Roberto Rigotto de Gouveia, diretor de tecnologia e métodos do Rural, o investimento do banco no serviço foi de US\$ 3 milhões.

A conexão do banco com a Internet está sendo fornecida pela Embratel. O empreendimento tem apoio da Telemig (Telecomunicaçōes de Minas Gerais).

\section{A Orientação do Governo}

Informa ainda Maria Ercilia, Folha de S. Paulo de 01-8-1995, E-7 que a Rede Nacional de Pesquisas (RNP) ligada ao Ministério da Ciência e Tecnologia, prometia iniciar nesse mesmo mês a operação comercial de um backborne brasileiro da Internet.

Backborne é a espinha dorsal, ou o tronco principal, de uma rede de acesso à Internet. A ele, empresas privadas ligarão seus computadores e venderão aos interessados, por uma taxa mensal, a conexão com a Internet.

$O$ backbone da RNP, que atende atualmente a comunidade acadêmica e 0 sistema de ciência e tecnologia brasileiro (estimado em 45 mil usuários), está sendo expandido para abrigar um tráfego misto (comercial e acadêmico). A RNP administra 0 acesso a Internet no Brasil desde administr.
1990.

Faz parte do projeto de expansão da RNP uma nova conexão internacional, desta vez entre Brasilia e os EUA - onde está concentrada a maior parte dos computadores da Internet.

Em abril os ministërios das Comunicações e da Ciência e Tecnologia Anunciaram que a RNP expandiria seu backbone, e passaria a fornecer acesso a empresas. A Embratel ficaria, segundo o governo, fora da competição no mercado de serviço a usuários finais

\section{Como Caracterizar Uma "Criação"}

\section{Eletrônica}

Pierre-Yves Gautier lembra que tudo começa com um projeto, formado por um empresário qque pode ser também um editor clássico, como um produtor de videogramas - e logo, não ha que duvidar, haverá a categoria hibrida de "editor eletrônico"), que vai se cercar de uma equipe de "criadores" cujo trabalho ele financiará e controlará.

Enumera os autores solicitados pelo empresário pertencentes aos diferentes gêneros da propriedade literária e artistica principalmente: escritores ou docentes, entenda-se redatores, para o texto: desenhistas e autores gráficos para as imagens: autores-compositores, para a música, peritos em informática, para a animação eletrônica e o "funcionamento" da obra: todos contribuirão na criação de uma obra hibrida, de um novo gênero, a "multimédia".

"Se a obra coloca em cena atores, recitando um texto ou interpretes de uma canção aqueles a estes serão contratados para que realizem sua prestação, destinada a ser integrada no produto final".

Em numerosos casos a obra "multimédia", incorporará assim textos, imagens ou músicas preexistentes, das quais nem os autores nem os intėrpretes terão participado à elaboração.

Isto leva à primeira qualificação de obra composta, subordinado sua criação e exploração ao acordo dos titulares da obra originária, exigindo pois a verificação quais os direitos implicados na exploração das obras "multimédia".

Separa os direitos em principais e derivados.

0 procedimento usado para realizar, duplicar e comunicar a obra "multimédia" consiste incontestavelmente numa reprodução, que melhor do que a lei pátria, "a cópia de obra literá- ria, cientifica ou artistica bem como de fonograma" (art. 4º, IV da Lei 5.988, de 14-12-1973) lei francesa art. 122-3 dá como "fixação material da obra mediante qualquer procedimento que permita comunicá-la ao público de um modo indireto... principalmente, gravação mecânica.. ou magnética" (por exemplo impressão sobre um suporte visual ou sonoro).

\section{PARTE III}

\section{A Importância da Programação} Cibernética

Não precisa ser ressaltada, tão lampejant se apresenta ao mais superficial dos observadores.

Lembro, em Software brasileiro sem misté rio, Campinas, Julex, 1988, 325 páginas, em que comento a Lei $n^{0} 7646$, de 18-12-1987 seu regulamento, artigo por artigo, ter sido apenas pouco antes da década de 50 que surgiram os enormes, pesadissimos e desajeitados computadores. O primeiro ENIAC, contava com 18 mil válvulas de 16 tipos diferentes, tinha $30 \mathrm{~m}$ de largura por três de altura, e consumia $140 \mathrm{~kW}$.

Acentua Enrico Caritá, já estamos no futuro in Evolução da Comunicação, um dos ensaios coordenados por Giovanni Giovannin, trad., Rio Nova Fronteira, 1987, p. 287, ter-se tornado difusão dos computadores um fenômeno imponente a tal ponto que chega a transformar profundamente a sociedade industrializada só com 0 advento da eletrônica.

"O mercado mundial dos circuitos integrados desenvolveu-se nos anos $70 \mathrm{com}$ ta xas de aumento médio de $35 \%$ ao ano, at alcançar em 1980 os 6 bilhōes de dólares. São 100 milhōes os microprocessadores que estima tenham sido fabricados em 1980, contra pouco mais de 2 milhōes em 1976. Para lelamente ao desenvolvimento do mercado ocorreu uma diminuição da mesma ordem de grandeza do custo por unidade de fun ção."

Para calcular a contribuição dos computadores à difusão do conhecimento é bastante con siderar - lembra Georges Koumantos - que bibliotecas do mundo inteiro poderiam ser con- tidas na memória de um computador por fio, cabo, ondas hertzianas ou satélites, e isso a velocidades miraculosas:

"Um mass medium inteiramente novo está por nascer. Somente os livros e as revistas tornam-se assim um lixo ultrapassado e embaraçoso: um só exemplar basta à divulgação universal de seu conteúdo, devidamente memorizado num computador. Mas qual será então a sorte dos autores e dos editores?"

Compendia a opinião geral Stephen B. Barnett, professor da Universidade da Califórnia, Berkeley, ao dizer que o direito ao respeito da fama não proporciona à pessoa celebre todos os valores econômicos que resultam de sua utilização "comercial".

Distingue a utilização entre aproveitá-los para fins comerciais e emprego com finalidades "informativas" ou de "diversão". Assim os jornais - inclusive os "diários" que se vendem nos supermercados têm liberdade de publicar fotos e artigos sobre a vida privada das celebridades: comediantes que aparecem em uma emissão de televisão (em oposição ao que ocorre nos comerciais de televisãol podem usar o nome e a aparência de pessoas célebres para divertir o público; biógrafos e cineastas podem contar "histórias da vida" das celebridades; e muitas outras utilizaçōes consideradas como feitas com finalidade de informação ou de divertimento são permitidas, Mas as utilizaçōes "comerciais" ficam submetidas ao controle da pessoa célebre."

\section{Uso do Banco de Dados}

Define Karen Hunter "retirada" (downloading) como o processo de transferir eletronicamente parte de um banco de dados de um computador remoto para um meio local de estocagem. Significa normalmente a captura local dos resultados de uma via de pesquisa de um arquivo de um de vendedor de banco de dados.

Embora muitos usuários creiam ter liberdade de uso, uma vez que essa retirada implica em fazer uma cópia de um trabalho protegido pelo direito de autor, a maior parte dos titulares de bancos de dados acreditam ser necessa permissão. Mas exatamente como ocorre com a 
fotocópia, essa retirada não pode realmente ser detectada e é considerada ser feita amplamente sem permissão.

Proibir eśsa retirada ė aborrecer os clientes policiar algo que normalmente não pode ser detectado quando ocorre é, na melhor hipótese, dificil.

0 que pode fazer quem tiver legalmente um banco de dados num computador local: guardá-lo para sempre? Alterá-lo, apagá-lo e acrescentar informaçōes, enviá-lo por rede a alguém mais, imprimi-lo a pedido e distribui-lo dai, mesmo vender esses impressos? Existem problemas em todos os cantos e curvas do caminho do uso do banco de dados.

Uma vez que o texto (ou outros tipos de in formação) é facilmente estocado, alterado, reusado e remetido ao redor do mundo de um computador local, a integridade do produto original e os direitos do titular do banco de dados estão em sério perigo.

Infelizmente não existem claras respostas a estas questões de direito de autor. No presente momento, a maioria dos editores tomaram a posição que um usuário deve obter permissão para qualquer coisa além de exibir a informação numa tela terminal - e talvez até para isso, se se considerar pagamento para acesso básico a um banco de dados como "permissão". Na prática, o uso ilegal é virtualmente incontrolável e somente as mais ruidosas violações de direito de autor, envolvendo normalmente revenda são apanhadas. A facilidade com que bancos de dados podem ser criados, manipulados e recondicionados deverão manter estudiosos de direito de autor e advogados dos editores em atividade. $\hat{E}$ de se presumir que os litigios aumentarão nos próximos anos.

Embora tenha limitado a discussão do impacto da tecnologia na publicação no sentido tradicional conclui Karen Hunter assinalando estar sendo desenvolvida uma nova geração de bancos de dados.

Alguns são compostos de imagens digitalizadas e indexadas. Outros são textos, mas levantados por numerosas pessoas num modo interativo, alguns por meio de um boletim eletrônico especial ou outra rede eletrônica de comunicação. Outros ainda, denominados "dados de conhecimento", são criados através do uso de técnicas de inteligência artificial. Estas novas formas de troca eletrônica de informação estão quase certamente abrigadas por inteiro ou em parte pela lei do direito de autor na maior parte dos paises. 0 levantamento dos pormenores especificos de cobertura apresentará questōes intrigantes para os especialistas em direito de autor nos anos por vir

\section{Imprensa e Informática}

Em oposição à apresentação gráfica (suporte em papel), que permite tomar conhecimento da obra "a olho nu" (mesmo que tenha passado, para sua confecção por um meio mecânico, p. ex., uma impressora), encarece Pierre-Yves Gautier a p. 99 ser a reprodução mecânica um meio indireto de comunicação, uma vez que o público não pode aceder à obra a não ser graças a um aparelho (aqui, as diferentes classes de leitores), para que esta lhes seja "restituida": esta distinção conforme o caráter imediatamente perceptivel ou não das obras, não é nova, e podemos encontrar por exemplo no art. VI da Conencão Universal, que define a publicacão como "colocação à disposição do público de exemplaes da obra que permitam lê-la ou dela tomar conhecimento visualmente".

Pierre-Yves Gautier invoca André Françon, Le droit d'auteur, aspects internationaux et comparatifs (Cours à l'Université Mac Gill, Ed. Blais, Montreal, 1993, pp. 8, 31 e 32: se se aplica o processo da apresentação gráfica às obras "multimédia" comprova-se a intervenção de vários elementos materiais: $0 \mathrm{CD}$ e seu leitor e se a obra é utilizada recorrendo a um computador, um "logical" apropriado ao tratamento da imagem, do som e dos textos, bem como a unidade central que 0 acolhe.

Conseqüentemente - acentua o Professor da Universidade de Caen - quem quer que explore a obra "multimédia" deverá normalmente obter o consentimento do titular do direito de reprodução sobre cada parte do conjunto: texto, imagens, logicial, música, para obter as necessárias autorizações aos utilizadores.

Após uma série de outras consideraçōes conclui que o fenômeno novo das obras "multimédia", como outras criações recentes propicia a ocasião de verificar a (grande) faculdade de assimilação da lei básica de direito autoral, sem que seja necessário modificá-la, como ocorreu com relação aos computadores. Só isso - alèm do prazer científico ou lúdico que estas criaçōes proporcionam ao usuário dá ocasião a um naural regozijo.

Eis ai matéria do mais alto interesse sob dois aspectos principais: 0 do direito à imagem, exigindo a verificação de como e quando é necessaria permissão para o seu aproveitamento, e o do direito de autor, pois escritos da mais variada natureza, canções, poesias, músicas e mesmo fotos, implicam não só nessa necessidade de permissão, como também para que possam ser efetuados os pagamentos prévios acaso devidos.

Para resolver - ou pelo menos encaminhar a solução do não fácil problema está sendo desenvolvido um sistema de localização de material particular.

O programa objetiva percorrer todos os caminhos da World Wide Web - acesso a imagens e textos da Internet para impossibilitar a veiculação ilegal desses textos.

\section{Direitos da Personalidade}

Forma por mim versados em duas vertentes principais em meu Tratado de Direito Civil, vol I, Parte Geral, Tomo II, ed. Rev. dos Tribunais, 1982, pp. 416-582.

0 primeiro: direito à vida, ao próprio corpo, às partes separadas do mesmo é matéria que dia a dia assume maior importância, a ponto de ter passado, das 104 páginas que lhe dedique na monografia Direito à Vida e ao Próprio Cor po, em 1986, na segunda edição, de 1984, para 389 , com novo material a ser constantemente acrescentado.

O segundo diz respeito à personalidade moral, destacadamente à integridade psíquica, à segurança, à honra, ao nome, a imagem, à intimidade, matéria esta última versada insuperavelmente pelo nosso mestre Milton Fernandes em Proteção civil da intimidade.

Ambos aspectos foram abordados, com a maestria de sempre, pelo também Professor Caio Mário da Silva Pereira em Direitos da Personalidade, Revista do Instituto dos Advogados de Minas Gerais, em sua nova fase, $\mathrm{n}^{\mathrm{0}} 1,1995$, Belo Horizonte, Del Rey, pp. 257-275.

Voltamos ao tema numa palestra proferida no dia 23-3-1994, no Tribunal Regional do Tra- balho da II Região sob o titulo Direito da Personalidade e Dano Moral, publicada na Revista Trimestral de Jurisprudência dos Estados.

Sob o prisma especial do Direito à intimidade ninguém até hoje versou o tema, quase vinte anos decorridos, melhor do que Milton Fernandes, em seu aludido clássico Protecão Civil da Intimidade, que bem mereceria ser reeditado, pouco tendo a ser atualizado.

Estuda a evolução histórica do instituto, "uma conquista do nosso tempo, sua natureza juridica, os elementos conceituais, 0 âmbito do sigilo, da intimidade doméstica, imagem, nome, reproduzindo a expressiva comparacão de um haystack in a hurricane - um monte de feno no ciclone, para entre preciosas consideraçōes, concluir conclamando todos os juristas a prosseguir na luta pela proposta concreta que apresenta, disciplinando a coleta de informações:

"Art. Toda pessoa tem o direito de acesso aos informes a seu respeito registrados por entidades públicas ou particulares e de correção dos erros que demonstrar existirem nestes dados.

Parágrafo único. Responde pelos danos materiais e morais que causar o órgão que transmitir informações errôneas."

Mas o enfoque que a ilustrada Diretoria deste nobre Instituto projeta na tela da informática é dos mais desafiadores e não poderia ser mais atual nem mais instigante: é o da captação dos direitos da personalidade nessa modernissima e tão mutante tecnologia.

Para dizer como é grande e variado esse exercício basta atentar a dois diferentes tópicos que se destacam por sua transcendência: do direito à imagem, que diz respeito não só a aparência fisica, principalmente ao rosto de uma pessoa, que tão facilmente pode sofrer alteraçōes ao ser apresentado: rejuvenescido, envelhecido, enrugado, deturpado, engordado, emagrecido, como também em seu aspecto moral, atingindo-lhe a honra, a tranqüilidade, a segurança.

O segundo, mais sublimado, é o da personalidade revelada através do mais excelso atributo do homem: o do criador intelectual o direito ao respeito à sua produção artistica, que tantas, tão fäceis e tão graves alterações e mutilacoos quase que fatalmente vem a sofrer ao ser processada pela informática. 
As considerações que até há poucos decênios eram referidas apenas à imprensa... impressa, passaram depois a alcançar também a TV, e hoje às manifestações audiovisuais informatihoje às manifestações audiovisuais informatizadas, que com tanta facilidade podem através
de redes, alcançar dezenas de milhares de usuários.

Com um agravante: tanto a imagem de uma pessoa, como suas manifestaçōes criativas podem, muito mais do que por efeito de espelhos deformantes, ser coloridas, viradas por todos os lados, aumentadas, diminuídas, deformadas, a ponto de nem sempre ser possivel reconhecerse a figura originária.

Dai porque multiplicam-se proporcionalmente os problemas já delicados inerentes à matéria.

Tomemos já o aludido CD-ROM, Tutto Felli$n i$, no titulo original italiano, ou "Fellini in $C D$ $R O M "$, na versão americana.

Até que ponto esse compêndio, em forma de narrativa cinematográfica sonorizada, substituirá a divulgação pela imprensa?

Demonstra Sérgio Augusto, da sucursal do Rio da Folha de S. Paulo de 12-7-1995, p. 6.3 enganar-se quem pensar que esse $C D$ compendia tudo quanto se tem escrito sobre o cineasta. Por um lado, é mais apaixonante o conteúdo dos livros e mais rápido o acesso às informações nele contidas, pois dispensa ligar o computador, por outro lado, o CD oferece algo mais do que os livros, som e imagem em movimento.

Embora o CD seja definido pelo jornalista carioca como um delicia, produzido com extrema competência, critica-o por deixar bastante a desejar em matéria de som e ação:

"Em nenhum momento temos a voz do cineasta ou de qualquer artista a ele ligado, poucos segundos duram as músicas de Rota, e os clipes dos filmes pecam pela baixa definição de suas imagens e pela exigüidade com que elas aparecem na tela.

Outra frustração: os três comerciais que Fellini dirigiu para a televisão são apenas listados. Não dá para entender por que não foram reproduzidos na integra.

Com material selecionado pelo critico do

"L'Ossercatore Romano", Sérgio Trasatti, "Tutto Fellini" tem portanto, muito mais textos do que imagens. São bons os textos, a maioria extraida da imprensa italiana."
Após mais algumas consideraçōes, conclui: "De fácil navegacão, o programa, que funciona em PC com 'Windows', passa em revisciona em PC com 'Windows', passa em reviscada filme ficha técnica (incompleta), sinopse, balanço critico, impressões do autor, adendos iconográficos e 30 segundos de imagens em movimento.

Um dicionário com 74 tópicos (filmes, circo, mulheres, cineastas, Rimini, neo-realismo, politica, TV, psicanálise, sexo etc.) sintetiza o pensamentó de Fellini, que, aliás era bem mais lúcido do que às vezes dava a entender."

\section{O Embate Entre a Liberdade de}

\section{Informação e os Direitos da Personalidade}

Dissertando a respeito do fenômeno da "erosão" da privacidade, encarece Luis Francisco Carvalho Filho que a imprensa não incomoda apenas quando ofende, quando invade sem motivo a vida privada, quando transmite a informação de maneira truncada ou mentirosa: incomoda no dia-a-dia muito, porque fiscaliza a ação dos homens públicos e os homens públicos se consideram intangiveis. Porque exerce 0 direito de crítica e em relação à crítica não há tolerância. Porque, personagens da noticia, pessoas preferem não ser personagens da notícia. Porque nem sempre reflete o sentimento da maioria e a maioria quer se impor à minoria. Porque fere a moral coletiva e contraria interesses.

Para que se evidenciem os problemas que envolvem a regulamentação da matéria, basta ter em mente que o Congresso Nacional é politicamente "suspeito" para legislar sobre o conflito. A instituição como um todo e os seus membros são alvos permanentes da fiscalização e da critica da livre imprensa no Brasil: é natural, portanto, que se desenvolva entre os parlamentares um sentimento de autodefesa em relação aos "abusos" e "irresponsabilidade" dos meios de comunicação. Mas a atribuição è sua, e é indelegável.

Encarece a necessidade de uma nova Lei de Imprensa, mediante promoção, pela Câmara dos Deputados, de uma ampla discussão sobre a matéria, revendo sem preconceito o texto aprovado pelo Senado, substitutivo do Senador José
Fogaça, Projeto de Lei $n^{0} 173 / 91$, que tem sérias imperfeiçōes técnicas e consagra um escândalo politico sem precedentes: anistia aos autodalo politico sem precedent
res de crimes eleitorais.

Aponta três grandes vertentes a partir das
Ade quais deve ser redigida a nova lei: a restrição dos abusos do poder econômico e do poder politico; a "desprisionalização" da solução dos conflitos (os crimes contra a honra - a calúnia, difamação e a injúria - não devem mais ser punidos com penas privativas da liberdade, adotando-se as tendências mais modernas do D reito Penal, abrindo-se espaço para o desenvol vimento da responsabilidade civil); e, finalmen te, a criação de procedimentos simples e capazes de cumprir sua função institucional.

Já aos 17 de fevereiro de 1992 advertia, no entanto, editorial de "O Estado de S. Paulo ser problemática a aboliçāo tão festejada de pena de prisão para os jornalistas, pelo menos enquanto os cidadãos comuns estiverem submetidos a esse tipo de pena cominada pelo Código Penal para os delitos contra a honra. Imaginese a seguinte situação: alguém injuria, difama ou calunia alguém em praça pública, é processado, condenado e preso. Se seu discurso, no entanto, estiver sendo transmitido pelo rádio e pela televisão, terá tão somente de pagar uma multa?

A propósito das penas pecuniárias, o projeto estabelece que elas levarão em conta, entre outros fatores, "o poder econômico do réu", que permitirá ao juiz multiplicar a multa por dez, se "a sanção máxima resulta insignificante". Não tem sentido aferir o grau de culpabilidade e, em conseqüência, o grau de punição merecida por critérios de natureza patrimonial.

\section{Limites do Direito de Informação}

Tal direito - escreve Bruno Jorge Hammes, p. 205 - é o mais amplo possivel a ponto de interferir freqüentemente em outros direitos fundamentais assegurados pela Constituição, como, por exemplo, o Direito de Autor. Não obstante, o direito de informaçāo tem os seus limites. Nem sempre é fácil determinar se o direito da coletividade à informação deve prevalecer ou se 0 individuo tem também uma esfera que o público, conseqüentemente a imprensa, deve respeitar. Dada a frequêencia e a intensidade dos conflitos de interesse, os dias de hoje mais e mais tendem a definir uma area de intimidade ou reserva que não deve ser liberada ao público sem 0 consentimento da pessoa interessada. Assim 0 direito de informaçāo deve ser o mais amplo possivel enquanto não conflitar com interesses considerados maiores. 0 interesse da coletividade em ser informada impõe a si mesma um limite, quando a divulgação de fatos venha a destruir a pessoa humana em sua dignidade e grandeza. 0 direito à informação existe em função do desenvolvimento da personalidade e não para a sua destruição.

Alguns exemplos demonstrarão a atualidade destas consideraçōes.

A lei sempre admitiu o direito de crítica (art. 49. III, da lei autoral). Assim a I⿳a Câmara do Tribunal de Justiça do Rio de Janeiro, (Distrito Federal) entendeu a 21 de setembro de 1933 , que não constitui "crime de critica" dizer que um escritor é ignorante ou um pintor "borrador de telas", ou um escultor "estraga-bronzes", ou que qualquer destes é mediocre, sendo suas obras sem valor, sem gosto, sem escola, sem arte, com falsos conceitos literários, científicos ou artisticos e bem assim dizer que alguém é "cavador, desde que não lhe atribua emprego de meios desonestos ou criminosos em suas "cavaçōes" - Revista de Jurisprudência Brasileira, vol. 21, p. 205.

"A critica de obras de arte, de literatura e de ciência, não é uma difamação, ainda que possa prejudicar a reputação artística, literária ou científica do autor e a sua fortuna". A critica literária, artistica e científica não constitui abuso da liberdade de imprensa. Lei $\mathrm{n}^{\circ} 2083$, de 12 11-1953, art. 15, e Lei no 5250, de 9.2.1967, art. 27, I.

A critica a pessoas especialmente expostas, em razão de cargos públicos, não pode ser tida por ilicita ainda que obnubile o prestigio politi-

Invoca decisão de 18.0-6.1974 do Tribunal Federal da Alemanha que "juizos de valor ofensivos à honra sobre pessoas determinadas em có ato de não comunicar simultaneamente ao leitor os fatos que lhe possibilitariam uma valoração crítica". O mesmo Tribunal Federal reconheceu que, em certas circunstâncias, as manifestações desairosas em processo civil não dão direi- 
to à ação cominatória. Segundo o Superior Tribunal Estadual de Hamburgo, o relato sobre doença de personalidade da vida pública na imprensa só daria direito à indenização em caso de grave ofensa à personalidade.

Rainer Klaka escreveu um valioso artigo so bre as expressões desairosas em processo civeis. Resume assim: "As alegações de caráter ofensivo só excepcionalmente são antijuridicas: se afirmação lesiva à honra ostensivamente não tem relação com a execução ou defesa dos direitos a relação com a execução ou defesa dos direitos a
que servem ou se conscientemente se fizerem afirmaçoos falsas ou ao menos levianas, que sejam evidentemente insustentáveis". De resto o próprio Tribunal Federal seria do entendimento que não se podem proibir expressões valorativas que firam o direito de personalidade ou horna. As partes de um processo dispõem de uma certa flexibilidade para valorações negativas na formulação de suas expressões. Um depreciação ou desprezo grave não seria admis sivel por não se justificar mais pelo interesse das partes na sustentação desimpedida e eficaz de seus pontos de vista.

Hermano Duval não contesta o direito de informação, mas alerta sobre a mercantilização do sofrimento alheio, quando a dramatização da noticia afeta a esfera da intimidade.

A Corte de Cassação da Itália nos fornece um caso (Clara Petacci) em que os direitos da personalidade (direito ao próprio corpo, ao nome, à própria imagem, sigilo epistolar) não induzem, por analogia a um direito, à esfera particular imperturbada (diritto alla riservatezza). Mas Constituição reconhece um direito de persona lidade à livre determinação no desenvolvimento da personalidade. Este direito é violado, quando se divulgam, sem autorização do interessado, noticias sobre a sua vida particular e não houver um interesse público preponderante na divulgação.

A relação informação e o direito de personalidade apresenta-se mais flagrante, quando individuo contribui para denegrir o próprio nome. O Superior Tribunal Estadual de Braunschweig, em decisão de 24-10-1974, teve ocasião de analisar o problema da violação de um direito de personalidade de uma pessoa suspeita de crime sobre a qual a imprensa havia noticiado. A violação está excluída, quando o interesse do público por informação prepondera sobre 0 in- teresse individual pelo anonimato. Assim 0 redator de jornal não age culposamente ao publicar informações policiais sobre os resultados de uma revista. A 1 de fevereiro de 1977, o Tribunal Federal da Alemanha mais uma vez se viu confrontado com um caso de afirmação valorativa. Tratava-se de critica feita em jornal de sindicato a um empresário tido por anti-social, chamando-o de "degolador". Embora em instância inferior tivesse sido reconhecido ao jornal o d relto de assim apelidar o empresário, o Tribu nal Federal não acompanhou tal decisão. Ponderou, entretanto, que nem sempre se podem impedir afirmações de valor, mas que o limite do licito está certamente ultrapassado, quando prevalece o conteúdo difamatório e injurioso.

\section{Divulgação de Fatos Relativos a}

\section{Personalidades Conhecidas}

Eis aí outra questão controvertida.

Temos, reiteradas vezes, manifestado o entendimento que, não implicando em desabono ou menosprezo, não há 0 que increpar à divulgação: são fatos, atos, acontecimentos, por assim dizer, pertencentes à história.

E na verdade, que trama mais envolvente do que a narrativa da vida e peripécias de tantos Ulisses dos dias de hoje? $\mathrm{E}$ a prova está que são cada vez mais numerosas biografias, filmes, novelas que só poderiam ser objeto de repressão ou sancóes caso atentassem contra a honra são ou sançóes caso atentassem contra a honra ou a dignidade das pessoas, ou quando violassem seu direito ao resguardo da própria intimidade.

Contam-se às dezenas os filmes, ou a intenção de produzi-los, sobre personalidades conhecidas. Entre nós principalmente depois que Lei no 568 de 10-7-1993, que cria mecanismos de fomento à atividade audiovisual e dá outras providências, autorizou os contribuintes a deduzir, até o exercicio fiscal de 2003, inclusive, as quantias referentes a investimentos na produção dessas obras brasileiras, três por cento do imposto devido pelas pessoas fisicas e um por cento do devido pelas pessoas juridica

Carmem Miranda, Vila Lobos, Senna, Lamarca, Olga Prestes, Pagu (Patricia Galvão), Elis Regina, o filme de cuja vida foi recusado pelo ex-marido e pelos filhos que não lhe desejam ver a vida particular devassada, Xuxa, que viu acolhida ação de perdas e danos por ter o filme Amor Estranho Amor de Walter Hugo Khouri. que a exibe nua no começo de carreira sido lançado em forma de video pelas locadoras, são alguns dos muitos casos recentes.

Na França levantou a polêmica de saber se os mortos têm o direito de ter a memória preservada a adaptaça tes Felinas do escritor, ator e diretor de cinem Cyril Collard, descrevendo sua convivência com a Aids e morte pouco depois de concluir a obra; em Londres, Thatcher - Os Dias Finais, produzido por Michael Cox, foi exibido no dia 11-91991, pela televisão, e Em nome do Pai, em cartaz no Brasil em maio de 1994 foi inspirado no drama de Paul Hill, inocentado por um tribunal de Belfast do assassinato de um soldado pelo qual cumpriu pena de 13 anos de prisão.

Nos Estados Unidos, o juiz federal Manuel Real, de Los Angeles, recusou o pedido de Lyle e Erik, os irmãos Menendez, que em 1989 mataram seus pais, alegando que sofriam abuso sexual dos mesmos, de proibir a exibição do filme Honrarás teu Pai e tua Mãe, baseado em sua história.

Filadélfia, que concorreu a cinco Oscars, retrata a vida de Martin Caprov, um advogado que contrai o virus da AIDS, é despedido e entra com um processo acusando a empresa de discriminação. Ganha no tribunal mas termina perdendo a vida. Isso é Hollywood. Mas a realidade é outra: 0 advogado, embora hospitalizado várias vezes, estava vivo e perdeu a causa: teria sido vitima da crise econômica e não de discriminação.

O ditador Manuel Noriega, no filme Noriega foi retratado pela Warner.

A Motion Picture Association of America e a Associação Americana dos Editores pediram a declaração da lei chamada "Son of Sam" que proibe no Estado de New York aos criminosos obter compensação pela venda de suas biografi-

E finalmente na China, depois de Mao, também sua mulher, Tsé-Tung teve seus primeiros anos de vida como atriz antes do casamento, referidos em Madame Mao produzido por Chen Kaige, regista do premiadissimo Adeus minha concubina.
Bem ilustrativo acórdão da $1^{\text {a }}$ Câmara Civil Corte de Cassação Francesa de 13 de fevereiro de 1985, publicado na Revue Internationale du Droit d'Auteur, $\mathrm{n}^{\circ} 125$, de julho desse ano, p. 145 confirmando aresto da Corte de Apelação contra qual se insurgiam Société G. R. Production e André Génoves, produtores do filme intitulado "Mesrine", por ter determinado a supressão de cenas relativas a diversos episódios da ligação amorosa entre Mlle. Jeanjacquot e Jacques Mesrine, depois da fuga dele e até sua

Sem embargo do caráter notório dos fatos a Corte de Cassação entendeu serem inoperantes as distinçōes entre seqüências relativas a fatos certos e exatos e outras em que houve alteração da verdadeira personalidade em causa: a medida excepcional de supressão deve ser limitada às cenas cuja divulgação seria de natureza a chocar mais profundamente a sensibilidade da interessada Silvia Jeanjacquot.

O Prof. Stephen R. Barnett, da Universidade da Califórnia, Berkely considera que a lei que governa 0 uso não consentido dos nomes, imagens ou "identidades" de pessoas célebres em publicidade é razoavelmente bem desenvolvida nos Estados Unidos como "right of publicity" criação das leis estaduais, não da federal, e existe em cerca da metade dos Estados, inclusive os dos mais importantes em matéria de indústria de entretenimento e publicidade: Califórnia e New York.

Define-o como o direito de uma pessoa - tipicamente uma celebridade - de não ter seu nome, imagem ou outro atributo usado para finalidades comerciais - especialmente em publicidade, sem seu consentimento.

Assinala que os Tribunais encontram dificuldade em admitir um direito de "privacidade" no caso de pessoas célebres, que por definição são pessoas públicas. $O$ desenvolvimento de um independente direito de "publicity" admite que, tenham ou não uma reivindicação à privacidade, as pessoas celebres têm um direito a receberem pagamento pelo valor comercial de seu nome, aparência ou outros atributos.

Conclui, por entre uma série de consideraçōes, que embora o "right of publicity" possa ser 
justificado, deve ser limitado de modo a proteger 0 interesse público na liberdade da palavra.

\section{Vão Freqüentando Cada Vez Mais os} Repertórios Arestos Relativos a Abusos de

\section{Imprensa}

Num rápido respingar entre casos recentes TJDF, ac. da $2^{\underline{a}}$ Turma Civel, publicado ao 08-9-1994, Ap. 32.153, Rel. Des. Getúlio Moraes, ADV. 67.543:

A lei de imprensa tem como escopo principal coibir 0 abuso e a irresponsabilidade dos meios de comunicação, sendo parte legitima passiva a empresa que explore jornal, periódico, radioemissora ou agência noticiosa. O dano moral, entretanto, cingido às pessoas envolvidas, tem reparação pelo direito comum em suas múltiplas variedades. 0 jornal, no caso, é apenas 0 meio de que se utiliza para produção do dano. Em tal caso a parte legitima pode ser aquela que concedeu a entrevista. As declaraçōes ofensivas à reputação, a honorabilidade, à segurança, à tranqüilidade, aos sentimentos afetivos, bem como aquelas que importem em calúnias, rendem ensejo à reparação civil. A fixação da indenização, na ausência de padrões legais específicos para o estabelecimento do valor, pode balizar-se pelos valores expressos na lei de imprensa.

O TJMT, pela sua $2^{\text {a }}$ Câmara, rel. Des. Benedito Pereira do Nascimento, reconheceu, aos 15 9-1992., Rev. Juridica (194): 93, no 7538 culpa configurada, imprudência e responsabilidade de empresa jornalistica na veiculação de noticias injuriosas e difamatórias através de jornal, acarretando prejuizo à imagem e à honra da vitima:

0 exercicio constitucional da liberdade de manifestação de pensamento e de informação, conferido à Imprensa, deve ser professado, posto que de interesse público, com responsabilidade e consciência, sempre comprometido com a verdade e respeitando a dignidade alheia. $\mathrm{Ca}$ racterizada a culpa pela veiculação leviana de notícia injuriosa e difamatória, surge a obrigação de indenizar a vitima pelos danos morais.

No Paraná, ac. un. da $4^{\mathrm{a}}$ Câm. do TJ, reg. em 26-12-1988, Ap. 1018, ADV. 43.956 admitiu visar-se na reparação por danos morais em conseqüência de carta publicada em jornal im- putando ação delituosa antes a compensacão ou reparação satisfativa a ser dada por aquilo que 0 agente fez ao prejudicado, não como no dano patrimonial, reposição em espécie ou em dinheiro pelo valor equivalente. À falta de disposição egal especifica, é razoável a aplicação, por analogia, do critério estabelecido nos art. 51 e 53 da Lei 5.250, de 1967, que regula a liberdade de manifestacão do pensamento e de informação, para a fixação da indenização, quando o agente não jornalista utiliza a imprensa para a ofensa moral

Invocou o Relator, Des. Wilson Rebak, a lição de Pires de Lima, da Universidade de Coimbra: "São dois os modos por que é possivel obter-se a reparação civil: a restituição ao estado anterior e a reparação pecuniária, quando o direito lesado seja de natureza reintegrável. Ora, a ofensa causada por um dano moral não é suscetivel de indenização no primeiro sentido, mas 0 é de uma reparação em dinheiro que em todo o caso se distingue da indenização exigida pelos danos patrimoniais. Com a indenização não se pretende refazer o patrimônio, porque este nem parcialmente foi diminuido, mas se tem simplesmente em vista dar à pessoa lesada uma satisfação que lhe é devida por uma sensação dolorosa que sofreu. Estamos em presença de puros danos morais e a prestação pecuniária tem neste caso, uma função simplesmente satisfatória. Se é certo não poderem pagar-se as dores sofridas, a verdade é que o dinheiro, proporcionando à pessoa disponibilidade que até aí não inha, lhe pode trazer diversos prazeres que até certo ponto a compensam da dor que lhe foi causado injustamente".

No TJRS, a $3^{\text {a }}$ Câmara deu provimento, em parte, à unanimidade, à apelação $\mathrm{n}^{0} 36.665-$ São Marcos, interposta por llair Teresinha Marcelino Ribeiro por si e representando seu filho menor A. M. R. contra aludida prefeitura, objetivando a reparação de danos morais decorrentes do uso depreciativo da imagem do mesmo, através de distribuição de sua fotografia, à revelia do consentimento materno, em jantar beneficente, Rel. Des. Marco Aurélio de Oliveira, RT 551/202:

Cabivel em nossa sistemática juridica a indenização por dano moral. Se, em tese, a inicial descreve situação que configura possivel dano moral, descabido o indeferimento liminar, pois presente a condição da ação da possibilidade juridica do pedido (12-02-1981).

O TJRJ, pela sua $3^{\mathbf{a}}$ Câm, em ac. un. reg. em 03-3-1989, Ap. 4.349, rel. Des. Ferreira Pinto, ADV. 45.769 considerou passivel de reparação a publicação que, ao noticiar caso rumoroso e de repercussão desagradável, empresta destaque a quem teve participação ventual e aciden tal. Os danos morais são passiveis de reparação, não merecendo ressarcimento por não provados os danos materiais. Improcedência da ação quanto a pessoas da familia não desenvolvidas no noticiário.

A $5^{\text {a }}$ Câmara, em ac. reg. em 26-10-1994 Ap. 4.418, Rel. Des. Narcizo Pinto, ADV. 69.480 em pedido de indenização por dano moral causado a membro do MP por reportagem ofensiva decidiu que o prazo para propositura da ação è o do art. 177 do Código Civil e não o da Lei de Imprensa, pois esta sô se aplica às hipóteses de crimes contra a honra, previstas no inc. I do art. 49 daquela lei. Evidenciando que as expressões ofensivas causaram um sofrimento moral à vitima, fixa-se a indenização em quantia condizente com as circunstâncias.

Votou em divergência o Des. Marcus Faver por considerar que "a citação não se realizou nos dez dias seguintes à prolação do prazo prevista no $\S 3^{\circ}$ do art. 219 do C.P.C. O juizo, na realidade, só determinou a efetivação da citação do réu em 23 de agosto (mais de um mês após o cite-se), sem contudo assinar o prazo de no máximo 90 dias para suprir a omissão. Assim, decaiu o autor de seu direito: seja pela falta do despacho determinatório da citação antes do prazo fatal; seja pela ausência de requerimento dentro dos cinco dias subseqüentes ao término do prazo previsto no $\S 2^{\circ}$ do art. 219 do Código de Processo Civil, objetivando a prorrogação do prazo para a realização da citação no prazo de 90 dias"

Comete ilicito de imprensa - decidiu ac. un. da 6 Câm. Reg. em 07-3-1995, Ap. 3.060, rel. Des. Pedro Ligiéro, ADV. 695532, - quem publica noticia deturpada, adjetivando as pessoas de modo a ofendê-las na sua honra. A expressão "boêmio", quando se refere a conduta, não tem a mesma significação quando é atribuida "à alma" das pessoas. 0 caráter malicioso, sensacionalista, adicionado a outras distorçoes, com conceituação duvidosa e sem a mínima preocupação de conhecer previamente o caráter e 0 juizo social das pessoas, patenteiam a assunção do risco de injuriar. Arbitramento. Sua dificuldade. Elementos de ponderação. Direito de resposta e retratação não se compensam com a indenização, totalmente.

A 8 câmara, também sem discrepância, reg. em 26-6-1990, Ap. 5.727, rel. Des. Carpena Amorin, ADV. 51.751:

Se o jornal deturpa a noticia verdadeira, publicando-a de forma escandalosa, deve responder pelo agravo moral que do abuso resulta. A Lei de Imprensa de 1967 disciplina os crimes perpetrados através dos meios de comunicação e dispõe, também, sobre a responsabilidade civil dos profissionais de imprensa, estabelecendo indenização tarifäria para suas transgressões, mas o princípio geral do Código Civil, que fundamenta a ação, de ampla reparação, não pode ser afastado, especialmente em razão da norma constitucional superveniente do art. 5o, item X. No STJ, ac. un. da $3^{\mathrm{a}}$ Turma, publ. em 10-91990, no resp. 2.327-RS, rel. Min Gueiros Leite, ADV. 52.048:

A empresa que explora jornal periódico, radioemissora ou agência noticiosa figura no pólo passivo da ação indenizatória por danos morais, toda vez que por qualquer desses veículos tenha sido divulgada a matéria causadora do dano - Lei 5250 de 1967, art. 49, § 2, o Recurso conhecido e provido.

Da responsabilidade, em tese, do entrevistado, é que decorre a sua legitimidade passiva para a ação penal, constituindo questão de mérito a autenticidade das declarações ofensivas constantes da entrevista. A retratação ou retificação espontânea do agente são causa de extinção da punibilidade que só operam quando satisfeitos os requisitos do art. $26, \S 2^{\circ}$, "a", da Lei de Imprensa; não se consideram, para esse fim, eventuais correções da publicação incriminada, divulgadas por outros veículos de comunicação. Tanto no Cód. Pen., quanto na Lei de Imprensa, interpelado em juizo o autor das declarações equivocas, não cabe ao Tribunal competente antecipar-se à propositura da ação se 0 fez, a decisão é nula e despida de eficácia. Nos processos por crime de imprensa, o interrogatório do acusado é meio de defesa e só se fará a seu pedido, ainda nos casos de competência origi- 
nária dos tribunais (STF - Ac. unân. da $1^{\mathrm{a}} \mathrm{T}$., publ. em 19-10-90 - HC 68.129-RS -Rel. Min. Sepúlveda Pertence, ADV. 52.038)

\section{Na Indenização dos Danos Morais Não Mais Prevalece a Tarifa dos Arts. 51 e 52 da} Lei $5.250 / 67$

Desprezando os parâmetros completamente desatualizados da Lei de Imprensa, jả são numerosas as decisões que fixam a indenização por danos morais em bases mais substanciosas.

Assim, o senador Ernandes Amorim vai processar a "Encyclopaedia Britannica do Brasil" por tê-lo acusado, à página 77 do "Livro do Ano mes (RO) de participar de uma "rede de narcotráfico que estaria sendo investigada pela Policia Federal." Nega todas as acusações, afirma cia Federal." Nega todas as acusaçōes, afirma
ter sido vitima de perseguiçōes de grandes empresas de mineração e de adversários politicos vai processar a Encyclopaedia por danos morais e exigir uma indenização de US\$ 2 milhões: "Se o Romário foi comprado por US\$ 5 milhōes porque eu não posso vender meu passe por US\$ 2 milhöes?" pergunta.

O ex-ministro da Justiça Bernardo Cabral, considerando-se ridicularizado e atingido moralmente em sua imagem pela publicação do livro Mil Dias de Solidão pelo porta-voz da Presidência da República no governo Collor, Cláudio Humberto Rosa entrou com um pedido e foi atendido, noticia Tribuna do Direito, S. Paulo, de maio de 1995, p. 5, pelo juiz Eduardo Almeida Prado Rocha de Siqueira, da $28^{\mathrm{a}}$ Vara Civel: todo o valor da arrecadação obtido com a venda do livro será entregue a ele. Silva não terá direito a absolutamente nada. A Geração Editorial e a Brasilivros Editora, responsáveis pela edição e distribuição do livro, foram excluidas da ação.

Segundo Cabral, o ex-porta-voz resolveu escrever o livro "por estar passando dificuldades financeiras" e, como não gostava pessoalmente do ex-ministro resolveu "relatar fatos de maneira distorcida, apresentando o autor (da ação) como canalha, desprovido de compostura para o exercicio do cargo que ocupava". Isso depois de pleitear a concessão de liminar para impedir a impressão do livro e apreensão dos exemplares que já haviam sido distribuidos.
Ao decidir a questão, o juiz entendeu ser "inegável" que a obra publicada "teve 0 escopo de fazer sensacionalismo gratuito, mencionando passagens intimas de nenhum interesse jornalístico, mas que atingiram a honra de um homem de maneira cruel e desnecessária, causando-lhe forte sentimento de vergonha e humilhação".

"Registro que face à projeção politica do autor, sua imagem e conceito são bens de valor incalculável. Mas ele, por questões de foro intimo, balizou modestamente o seu pedido, apenas no proveito econômico obtido pelo réu com a publicação do livro, sendo portanto este 0 valor máximo que pode ser fixado em juizo" (art. 460 do C.P.C.)

Acórdão da $4^{\mathrm{a}}$ Câmara do TJSP, por v.u. de 20-12-1990, deu provimento à $\mathrm{AC} \mathrm{n}^{0} 128.589$ - São Paulo da sentença do Juiz Manoel de Lima Júnior, que em 01-8-1989, que julgou procedente ação ordinária de indenização por danos morais e materiais movida pelo Delegado de Polícia Alvaro Vicente de Luca contra S. A. O Estado de São Paulo por ter publicado o Jornal da Tarde, na edicão de 17-7-1985, matéria difamatoria, abusando da liberche de imp esando a honra do autor, dizendo que este praticou crime contra a administração pública, anotando que com seus vencimentos de delegado de polícia não poderia reunir seu atual patrimônio e apontando-o como contrabandista e dado à prática de tráfico de influência, fatos eses que não são verdadeiros; em 18/07/85, co que "O sabol", que circ contra "O Liberal", que circula na cidade de mericana por ter reproduzido a noticia.

Considerando sua posição social, sua situação de funcionário público, seu sofrimento moral, a natureza e repercussão de lesão, bem como a situação econômica das empresas rés, pediu reparação indenizatória de danos morais e materiais, que estimou em 10.000 ORTN's.

Ponderou o Relator, Des. Ney Almada, dever a Imprensa, de modo geral, cuidar diligentemente ao publicar noticias que possam agravar a honra de alguém, poupando-se sempre ao sensacionalismo e atuando com provas que respaldem sua informação. Sensacionalismo, aliás, de que prescindem os órgãos de imprensa de maior notoriedade do mundo, em cujo elenco figuram os da primeira empresa demandada.
A liberdade de informação esbarra nas fronteiras intransponiveis da esfera ético juridica da pessoa humana, sob pena de se transforma numa incontrolável arma de vulneração da honra alheia. Não é outro o pressuposto determinante da tutela desse valor juridico pela Lei de Imprensa e pela que regula, em nosso Pais, as telecomunicações, além de dispositivos do $\mathrm{C}$. Civil revestidos de idêntico escopo.

0 veiculo pelo qual o individuo atingido pode concorrer para a frenação dos impulsos injustos da Imprensa é, unicamente, a demanda judicial, ativando o Judiciário no sentido de san cionar os assédios aos mais preciosos sentimentos da personalidade do homem, notadamente a honra em seu aspecto objetivo, em cuja conotação interessa o que os outros pensam acerca do cidadão relativamente a seu modo de proceder e à utilização, nos atos profissionais ou não de seus predicamentos fisicos, intelectuais, culturais e outros.

Note-se, em seguida, que a extinção da ORTN antecedida por sua conversão em OTN, não prejudica o atendimento do "petitum", bastando que, no cálculo da indenização, seja aproveitado o IPC de janeiro e fevereiro de 1989, e, ulteriormente, o indice que então surgiu, e presentemente ainda se presta como referência (BTN). A verba advocaticia é inteiramente mantida.

Comemorando a árdua vitória, os advogados Paulo Esteves, Sérgio Toledo e Salo Kibrit publicaram em 1991 um folheto em que encarecem, em sua apresentação que o critério de indenização tarifada dos arts. 51 e 52 da Lei n $5250 / 67$ colide com o texto do art. 159 do $\mathrm{C}$ C., excepcionando o principio de que a indenização deve ser a mais ampla possivel - foi acolhido por todas as decisōes proferidas em açōes de reparação de dano moral, ajuizadas com fundamento nessa legislação de regência.

$\mathrm{A} \mathrm{CF} / 88$, no entanto - e em boa hora, visto que, segundo acreditamos, a limitação do valor da indenização por dano moral prevista nos arts. 51 e 52 da Lei 5.250/67 deveu-se aos longos habilidosos trabalhos desenvolvidos pelas poderosas empresas que atuam no campo das comunicações - estabeleceu a inviolabilidade da honra, assegurando o direito de indenização do dano moral decorrente de ofensa praticada contra ela e determinou que o seu montante ser proporcional ao agravo sofrido $(\mathrm{CF} / 88$, art. 5․ incisos V e X).

Na demonstração de que aqueles dispositivos tornaram-se ineficazes por incompativeis com a nova ordem juridica, restabelecendo-se então, o critério de que a indenização por dano moral, a exemplo daquela devida por dano material, deve ser a mais ampla possivel, dentro do texto do art. 159 do C. C., transcrevem a fundamentação do aludido acórdão da $4^{\mathrm{a}}$ Câmara:

.. a composição do dano moral poderá, em termos, aproveitar-se do critério preconizado na Lei de Imprensa, mas terá por alicerce primacial o lapidar preceito do Código Civil, art. 159. O pedido de ressarcimento é, de regra, genérico, porque a indenização deve ser a mais ampla possivel; na hipótese, contudo, o autor cingiu sua pretensão em 10.000 ORTNs. O Projeto 634-B, art. 186, não limita o "quantum" da indenização por dano exclusivamente moral, nem se refere à sua moderação. Deixa o problema acertadamente, a critério do Juiz.

Aditam ter agora, enfim, esse acórdão removido da ordem juridica o desarranjo nela provocado por aquela esdrúxula limitação, demonstrando essa fundamentação sua atualidade e importância:

Afastou ela, finalmente, o dano juridico causado pelo legislador de 1967 ao vedar a aplicação do art. 159 do C. C. no plano de abuso da liberdade de informação, dispensado a essa modalidade de ato ilicito um tratamento diferenciado e significativamente protetivo em relação aos órgãos de comunicação, tudo através do expediente de tarifar o dano moral

Chegou-se, então, ao absurdo de uma avaliação, previa e genérica, da honra humana, que, em hipótese alguma, poderia valer soma superior a de duzentos salários minimos.

A E. 4a Câmara Civil do TJSP, agora, enfim, removeu da ordem juridica o desarranjo nela provocado pela esdrúxula limitação.

A Rede Globo foi condenada a pagar R\$ 720 mil de indenização para o radialista e deputado Afanasio Jazadji (PFL), em sentença do juiz da 20 $0^{\mathrm{a}}$ Vara Civel (SP), segundo notícia do dia 018-1995.

Jazadji alega que foi prejudicado pela associação de sua imagem com o personagem Juca 
Pirama, da novela "O Salvador da Pátria", exibida em 1989.

Foram condenados ainda a retransmissora da Globo em São Paulo e o autor da novela, Lauro César Muniz. Para ambos, a quantia a ser paga é de $\mathrm{R} \$ 40 \mathrm{mil}$.

Jazadji alegou que Juca Pirama era baseado em sua imagem. Só que era também traficante.

Os advogados da Rede Globo e de Muniz vão recorrer. Eles dizem que a pericia não apontou coincidência entre Pirama e Jazadji.

No STF, a $1^{\text {a }}$ Turma, por v. u. de 23-3-1982 Rev. Juridica das Comunicações, (1): 45-52, jan/ jun. 1983, RHC 59.290-RS:

Crime contra a honra. Crime de imprensa. Pessoa juridica. Legitimidade passiva ad causam. Lei $\mathrm{n}^{0} 5.250 / 67$. Inquestionável, pela Le de Imprensa, ser a pessoa juridica passivel de de Imprensa, ser a pessoa juridica passivel de
crime contra a honra, controvertendo-se apenas crime contra a honra, controvertendo-se apenas
sobre a compatibilidade de tal ou qual das figuras penais (calúnia, difamação, injúria) com a referida sujeição passiva. Responsabilidade penal. Queixa crime (omissão). Ofensas radiofônicas. Responsabilidade sucessiva. Diretora-Presidente da Rádio (art. 28 da Lei no $5.250 / 67$ ). Se a queixa-crime não traz as razões ou circunstâncias pelas quais incrimina o querelado, invocando abstratamente 0 último degrau da responsabilidade sucessiva sem exaurimento das escalas precedentes, importa omissão relevante que a torna inepta, no ponto, sendo causa de constrangimento ilegal. Habeas-corpus concedido para excluir a segunda Querelada. recurso de habeas-corpus provido, em parte.

Considerando, em primeiro lugar, a questão relativa à pessoa juridica como sujeito passivo de crimes contra a honra, assinala o Relator Min. Rafael Mayer, que o equacionamento deve ser afirmativo, mesmo no campo do direito penal comum, com os temperamentos que se impõem, reiterando o que teve oportunidade de asserir no RHC 57.668:

"Considero que, para que se entenda subs sumir na espécie penal comum as pessoas juridicas, nos arts. 139 e 140 do Código Penal (crime de difamação), não é necessária interpretação analógica, bastando uma interpretação compreensiva da lei penal. $\mathrm{E}$ justifico, porque, como eu dizia:

"Cada vez mais a atividade humana se expressa, no complexo mundo moderno, em forma de comunidades ou sociedades personificadas. Fungindo aos extremos quer da teoria organicista, quer da teoria ficcionista, importa reconhecer que as pessoas juridicas importa reconhecer que as pessoas juridicas to, porquanto emergem de um substrato $\mathrm{so}^{+}$ cial especifico complementada pela realidade técnico-juridica, constituindo centros de imputação de direitos, interesses e deveres sob a proteção real entre a personalidade dos individuos e dos entes coletivos, a estes nem todos os direitos inerentes à pessoa natural todos os direitos inerentes à pessoa natural
se aplicam, mas por ser limitada a extensão se aplicam, mas por ser limitada a extensão
nem por isso estả excluída. Ora, não se pode recusar às pessoas juridicas o direito à reputação, à respeitabilidade e à incolumidade moral, no plano de convivio social, bens de moral, no plano de convivio social, bens da vida que estáo sob a proteção do art. 139 do Código Penal. Nem se compreenderia, senão sob a total reputação do minimo ético que o próprio Direito Penal visa resguardar, que tais seres sociais e juridicos, expressões da vida humana, se vissem expulsos das normas de protetivas dos valores morais do bom nome e da respeitabilidade e expostos, sem remissão, à execração na vida social."

A fortiori, se há de admitir com relação aos crimes de imprensa, posto que especificamente contemplada a hipótese na Lei $\mathrm{n}^{0} 5.250 / 67$. Basta ver que 0 art. 21, que trata da difamação, admite a excecão de verdade, se o crime é praticado contra óna ou entidade que exerç funcart. 23 , inclui dentre os sujeitos passivos, que suscitam a agravação da pena, nos crimes dos arts. 20,21, 22 (calúnia, difamação e injúria) o órgão que exerça função de autoridade pública.

Aliás, no tocante a crime de imprensa, a controvérsia sobre a questão da passibilidade da pessoa juridica em crime contra a honra, não se situa no principio, sempre admitido, mas na extensão, a saber qual das figuras penais é compativel com a sujeição passiva das pessoas morais ou juridicas. Em face disso, excluo o fundamento.

Demonstra ser patente a omissão da queixacrime no indicar a razão da responsabilidade penal da paciente pela divulgação da nota tida por injuriosa e acrescenta que, por outro lado, a simples e isolada invocação de sua qualidade de Diretora-Presidente da sociedade proprietá- ria da emissora não é fundamento bastante para incriminá-la.

Diz a Lei $n^{0} 5.250$, de 1967

"Art 28

$\S 1$ Nas emissōes de radiodifusāo, se não há indicação do autor das expressões faladas ou das imagens transmitidas, é tido como seu autor:

a) o editor ou produtor do programa, se declarado na transmissão;

b) o diretor ou redator registrado de acordo com 0 art. $9^{\circ}$, inciso III, letra $b$, no caso de programa de noticias, reportagens, comentários, debates, ou entrevistas;

c) o diretor ou proprietário da estação emissora, em relação aos demais programas.

Ora, a invocação do último degrau da responsabilidade sucessiva, sem qualquer indicação das atribuiçōes estatutárias ou contratuais da paciente, e sem dar a razão do exaurimento das escalas precedentes de responsabilidade, é omissão injustificável, tanto mais que se recorre a uma responsabilidade objetiva e automática, sem a irrogacão de uma conduta individual. Registre-se que, como se vê da queixa-crime, os fatos incriminados vieram em um programa noticioso, em relação ao qual a própria lei indica o responsável, de modo certo, como o direto ou redator, obrigatoriamente registrado, nos termos do art. 9º, III, b.

Ora, a queixa-crime deve trazer as razões ou circunstâncias pelas quais incrimina o querelado, por sua presunção de responsabilidade que, por isso mesmo que é presumida, deve conter
todos os elementos que a suscitem. Sem isso, há um constrangimento ilegal em responder a processo-crime, sendo inepta a denúncia po omissão dessas relevantes circunstâncias.

Assim, dou provimento, em parte, ao recurso, para excluir da querela a paciente Mathilde Salette Verceliano Mânica.

\section{BIBLIOGRAFIA}

BARNETT S.R. At a Crossroads: the right of publicity in the United States. Revue Internationale du Drolt d'Auteur, Neuilly-S/Seine, n. 160, pp. 5-90, abril

keness and "Identities" in Advertising. America" "Reness and "ldentlies" in Adverting. America's rência anual da International Association for the Advancement of Teaching and Research in Intellectual Property - ATRIP, Ljubljana, 11-13 Julho 1994 tual Property - ATRIP, Ljubljana, 11-13 Julho 1994 ph Straus (ed), pp. 40-83, 1995

ph Straus (ed), pp. 40-83, 1995.
CARVALHO FILHO L.F. Liberdade de Imprensa e Dano Moral. Revista do Advogado, S. Paulo, n. 38, pp. 17 . 21, dez. 1992.

"Outdoor" Video Eletrônico. In: ADV Informativo, p. 118, 1987.

- Obra Cinematografica e sua Reprodução por Videocassete. Revista Trimestral de Jurisprudência dos Estados. São Paulo, v. 129, pp. 19-31, mar., 1995. . Direitos da Personalidade e Dano Moral, RJTE citada, v. 134, pp. 19-31, mar., 1995.

DIAS J. de A. Dano Moral e Abuso de Imprensa. Sele çoes Juridicas ADV, Rio, p. 15-16, junho 1987.

ERNANDES M. Proteção Civil da Intimidade. São Paulo Saraiva, 1977, 315p

CAUTIER P.-Y. Les oeuvres "multimedia" en droit fran cais. Revue citada, v. 160, pp. 91-131.

RUNWALD H.A. Precisa-se: Um Novo Jornalismo. Di álogo, Rio, n. 3, v. 27, pp. 62-67, 1994.

B.J. O Jornalismo e o Direito do Autor. São Le年,

UUNTER $K$. New Technologies, Publishing and CopyriNTER K. New Technologies, Publishing and Copyrthe An Introduction to Database Publishing, in RiCreativity, Genebra, verão 1987, v. I, n. 2, pp. 1 e 12-15.

LANE S. \& BRIDGE R.MCD. Dramatic Formats: why we need a format right. Opinion, Londres, 12 laudas xerox, 1990.

MIRANDA D.A. Comentários à Lei de Imprensa, São Paulo, Revista dos Tribunais, 3.ed., 1995.

OLIVEIRA A. A imprensa, sua missão e sua liberdade, Rev. de Inf. Legislativa, Brasilia, pp. 97-112, abr./ jun. 1972

PASSOS J.J.C. de. A imprensa, a proteção da intimidade e. o progresso penal. Rev. Forense. Rio de Jane ro, v. 324, pp. 61-67, out./dez. 1993.

PEREIRA J. A informaçáo no Direito. $O$ Estado de $S$. Paulo, p. 36, 17-02-1985. 